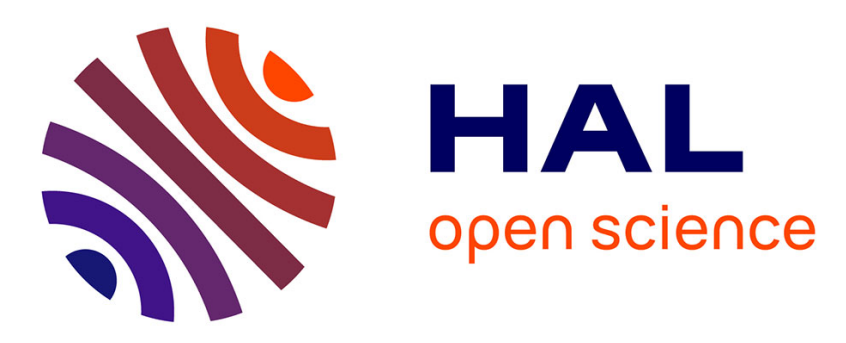

\title{
Heteropolysaccharides from S. cerevisiae show anti-adhesive properties against E. coli associated with Crohn's disease
}

Adeline Sivignon, Shin-Yi Yu, Nathalie Ballet, Pascal Vandekerckove, Nicolas Barnich, Yann Guerardel

\section{To cite this version:}

Adeline Sivignon, Shin-Yi Yu, Nathalie Ballet, Pascal Vandekerckove, Nicolas Barnich, et al.. Heteropolysaccharides from S. cerevisiae show anti-adhesive properties against E. coli associated with Crohn's disease. Carbohydrate Polymers, In press, 271, pp.118415. 10.1016/j.carbpol.2021.118415 . hal-03373401

\section{HAL Id: hal-03373401 https://hal.univ-lille.fr/hal-03373401}

Submitted on 12 Oct 2021

HAL is a multi-disciplinary open access archive for the deposit and dissemination of scientific research documents, whether they are published or not. The documents may come from teaching and research institutions in France or abroad, or from public or private research centers.
L'archive ouverte pluridisciplinaire HAL, est destinée au dépôt et à la diffusion de documents scientifiques de niveau recherche, publiés ou non, émanant des établissements d'enseignement et de recherche français ou étrangers, des laboratoires publics ou privés. 


\title{
Heteropolysaccharides from $S$. cerevisiae show anti-adhesive properties against $E$. coli associated with Crohn's disease
}

Adeline Sivignon ${ }^{a, 1}$, Shin-Yi $Y^{b, 1}$, Nathalie Ballet ${ }^{c}$, Pascal Vandekerckove ${ }^{c}$, Nicolas Barnich ${ }^{a, 2}$, Yann Guerardel $\mathrm{b}^{\mathrm{b}, \mathrm{d}, 2, *}$

a Université Clermont Auvergne/Inserm U1071; USC-INRAE 2018, Microbes, Intestin, Inflammation et Susceptibilité de l'Hôte (M2iSH), Clermont-Ferrand, France.

b Univ. Lille, CNRS, UMR 8576 - UGSF - Unité de Glycobiologie Structurale et Fonctionnelle, Lille, France.

' Lesaffre International, Lesaffre group, 59700, Marcq-en-Barœul, France.

d Institute for Glyco-core Research (iGCORE), Gifu University, Gifu, Japan

${ }^{1}$ These authors are co-first authors and contribute equally to this work

${ }^{2}$ These authors are co-last authors and contribute equally to this work

* corresponding author

\begin{abstract}
The Saccharomyces cerevisiae CNCM I-3856 was previously reported to strongly inhibit adherent-invasive Escherichia coli (AIEC) adhesion to intestinal epithelial cells in vitro and to favor AIEC elimination from the gut in a murine model of Crohn's disease in vivo. In order to identify which cell wall components of yeast are responsible for AIEC elimination, constituent polysaccharides of yeast were isolated and their antiadhesive ability against AIEC adhesion in vitro were screened. A fraction containing mannan, $\beta$-glucan and $\alpha$-glucan extracted from yeast cell-walls was shown to inhibit $95 \%$ of AIEC adhesion in vitro and was thus identified as the strongest anti-adhesive yeast cell wall component. Furthermore, this mannan-glucancontaining fraction was shown to accelerate AIEC decolonization from gut in vivo. This fraction could be proposed as a treatment to eliminate AIEC bacteria in patients with Crohn's disease, a microbial trigger of intestinal inflammation.
\end{abstract}




\section{Highlights}

- Mannan extracted from yeast inhibits $E$. coli adhesiveness to intestinal cells in vitro.

- A soluble fraction containing $\beta$-glucan/ $\alpha$-glucan/mannan (GGM) was extracted from S. cerevisiae cell wall.

- This soluble GGM fraction strongly inhibits $E$. coli adhesiveness to intestinal cells in vitro.

- This soluble GGM fraction favors elimination of $E$. coli from gut in vivo.

Keywords: mannan-glucan heteropolysaccharides; Adherent-Invasive Escherichia coli; Saccharomyces cerevisiae; anti-adhesive strategy; NMR analysis

Abbreviations: AIEC, adherent-invasive Escherichia coli; CD, Crohn's disease; CEACAM6, carcinoembryonic antigen-related cell adhesion molecule 6; YCW, yeast cell wall; Man, mannose; Glc, glucose; PPM, phospho-peptido-mannan; GGM, $\beta$-glucan/ $\alpha$-glucan/mannan 


\section{Introduction}

Inflammatory bowel diseases (IBD), including Crohn's disease (CD) and ulcerative colitis (UC) cause a dysfunction of the immune response to gut microbiota occurs. Among those, Crohn's disease (CD) leads to a reduction of global microbial diversity and an increase in mucosal bacteria in patients (Gevers et al., 2014; Manichanh et al., 2006; Sommer et al., 2017). Into this context, ileal mucosa-associated microbiota at time of surgery was shown to be predictor of post-operative endoscopic recurrence in CD (Sokol et al., 2019). Among this mucosa-associated community, Enterobacteriaceae, and particularly the Escherichia coli species, are over-represented at the ileal mucosa of CD patients (Martin et al., 2004) (Baumgart et al., 2007) (Lopez-Siles et al., 2014). Abnormal prevalence of $E$. coli was observed worldwide in CD patients (Agus, Massier, Darfeuille-Michaud, Billard, \& Barnich, 2014). These CD-associated E. coli possess adherent and invasive properties in vitro on intestinal epithelial cells, the defining characteristics of this pathobiont of E. coli that confers its name, "Adherent-Invasive E. coli" (AIEC) (Boudeau, Glasser, Masseret, Joly, \& Darfeuille-Michaud, 1999; Darfeuille-Michaud et al., 1998; Eaves-Pyles et al., 2008). Besides the adherent and invasive phenotypes, AIEC invade and replicate inside macrophages, which induces elevated secretions of pro-inflammatory cytokines TNF- $\alpha$, and promotes granuloma in vitro (Bringer, Glasser, Tung, Meresse, \& Darfeuille-Michaud, 2006; De la Fuente et al., 2014; Glasser et al., 2001; Meconi et al., 2007). Furthermore, AIEC bacteria induce or aggravate intestinal inflammation in various models of mice (Carvalho et al., 2008; Carvalho et al., 2009; Eaves-Pyles et al., 2008; Small, Reid-Yu, McPhee, \& Coombes, 2013). Therefore, it appears essential to develop therapies targeting AIEC in CD patients in order to eliminate a triggering agent of intestinal inflammation.

Anti-adhesive strategy could be of interest to the eradication of AIEC from the gut by focusing on the initial step of virulence: attachment to ileal mucosa. Bacterial adhesin FimH, located at the tip of the type 1 pili, recognizes mannose (Man) residues on host cells (Abraham, Sun, Dale, \& Beachey, 1988). AIEC possess genetic polymorphisms in fim $\mathrm{H}$ that allow them to bind strongly to mannose residues on intestinal epithelial cells (Dreux et al., 2013). The glycoprotein carcinoembryonic antigen-related cell adhesion molecule 6 (CEACAM6) was shown to be overexpressed at the ileal mucosa of CD patients (Barnich et al., 2007). AIEC reference strain LF82 preferentially persists in the gut of transgenic mice expressing the 
human CEACAM6 protein (CEABAC10 mouse model) (Carvalho et al., 2009), demonstrating that oligomannosylated glycans exposed by CEACAM6 provides to AIEC increased opportunities to bind to the intestinal mucosa.

From 1980's, type 1 pili-mediated interactions between enterobacteria and host cells were characterized using yeast agglutination assays (Eshdat, Speth, \& Jann, 1981). Because of the numerous mannose residues exposed on the yeast cell surface, yeasts can bind type 1 pili-expressing bacteria and thus, can act as a competitive inhibitor of the ligand system, preventing bacterial attachment to the host cells. Saccharomyces cerevisiae CNCMI-3856 was previously selected for its high ability to agglutinate AIEC bacteria and to prevent bacterial attachment to intestinal epithelial cells in vitro (Sivignon, de Vallee, et al., 2015). In CEABAC10 mice, oral administration of S. cerevisiae CNCM I-3856 accelerated AIEC elimination from the gut and decreased the subsequent symptoms of colitis. Interestingly, crude extracts enriched in yeast cell wall still possess beneficial effects against AIEC infection in mice (Sivignon, de Vallee, et al., 2015).

In this study, the nature of glycoconjugates from $S$. cerevisiae that exert the anti-adhesive ability against AIEC was investigated in order to identify the active part of the yeast and to develop a rationally defined probiotic-based medicinal product targeting AIEC bacteria. Yeast mannan exerts good inhibition properties against AIEC. In comparison, a glycoconjugate fraction composed of mannan, $\beta 6$-glucan, and glycogen together was shown to exhibit much superior anti-adhesive effect in vitro and in vivo. This work presents new alternatives in personalized antimicrobial therapies in $C D$, and more generally, to various pathologies involving type 1 pili-expressing enterobacteria.

\section{Material and methods}

\subsection{Materials}

All yeast products used in this study were provided by the Lesaffre Group (Marcq-en-Baroeul, France). CNCM I-3856, LV04 and LV08 are active live Saccharomyces cerevisiae yeasts commercially available in dry form. CNCM I-3856 is a patented probiotic yeast strain registered in the French National Collection of 
Cultures of Microorganisms (CNCM) under the number I-3856. LV04 is a specific yeast strain used in the bioethanol production process. LV08 is a specific yeast strain used in the beer high fermentation (Ale). YCW CNCM I-3856 and YCW CNCM I-5268 are yeast cell wall fractions obtained from primary culture and then the autolysis of yeast cells from respective strain CNCM I-3856 and CNCM I-5268 (Reed \& Nagodawithana, 1991). After cell lysis is completed, the soluble intracellular fraction (the yeast extract) is separated from the insoluble yeast cell wall fraction by centrifugation. Obtained yeast cell walls are then spray dried.

\subsection{Purification of mannan fraction}

$50 \mathrm{~g}$ of yeast product (either whole yeast or yeast cell wall) was suspended in $300 \mathrm{~mL}$ of $0.02 \mathrm{M}$ citrate buffer ( $\mathrm{pH} 7$ ), autoclaved at $121^{\circ} \mathrm{C}$ for $90 \mathrm{~min}$. After autoclaving, the yeast extracts were cooled down, followed by centrifugation at $4300 \mathrm{~g}$, at $4{ }^{\circ} \mathrm{C}$ for $30 \mathrm{~min}$. The supernatant was collected, and the pellet was suspended in another $300 \mathrm{~mL}$ of $0.02 \mathrm{M}$ citrate buffer, autoclaved at $121^{\circ} \mathrm{C}$ for 90 min followed by centrifugation again. Two supernatants were pooled together, called crude mannan. The pellet was kept for the extraction of glucan, which was described in section 2.4 .

The conventional method to purify mannan uses Fehling solution through copper-mannan complex precipitation (Kocourek \& Ballou, 1969). Fehling solution was prepared freshly by mixing equal volume of two prepared solutions; one solution contains $35 \mathrm{~g}$ of copper(II) sulfate pentahydrate, $5 \mathrm{~mL}$ of $2 \mathrm{~N}$ sulfuric acid, addition of water until a final volume of $500 \mathrm{~mL}$, and the other solution contains $87.5 \mathrm{~g}$ of potassium sodium tartrate, $38.5 \mathrm{~g}$ of sodium hydroxide in $500 \mathrm{~mL}$ of water. Fehling solution was added to the pooled supernatant (supernatant: Fehling solution, 1:1 v/v), and stirred overnight at $4^{\circ} \mathrm{C}$. The mannan-copper complex was formed, and the precipitate was collected by centrifugation $4300 \mathrm{~g}$ at $4^{\circ} \mathrm{C}$ for $30 \mathrm{~min} .100$ $\mathrm{mL}$ of $3 \mathrm{~N} \mathrm{HCl}$ was added to the precipitate, and stirred at $4^{\circ} \mathrm{C}$ until the precipitate was dissolved to dissociate the mannan from copper. Another $300 \mathrm{~mL}$ of ethanol was added to precipitate mannan, and stirred overnight at $4^{\circ} \mathrm{C}$. The white precipitate corresponding to mannan was collected by centrifugation at $4300 \mathrm{~g}$ at $4{ }^{\circ} \mathrm{C}$ for $30 \mathrm{~min}$. The mannan precipitate was re-dissolved in $50 \mathrm{~mL}$ of water and put into 
dialysis membrane (MWCO 3500) against $1 \mathrm{~L}$ of water, then stirred overnight at $4{ }^{\circ} \mathrm{C}$. The dialyzed mannan was collected and lyophilized.

\subsection{Acetolysis of mannan}

Dried mannan was aliquoted into $50 \mathrm{~mL}$ beaker, and $10 \mathrm{~mL}$ of $100 \%$ acetic acid, $10 \mathrm{~mL}$ of acetic anhydride, $1 \mathrm{~mL}$ concentrated sulfuric acid were subsequently added into beaker under hood and stirred at room temperature for $24 \mathrm{~h}$. Then, solution was transferred into glass tube, followed by centrifugation at $4500 \mathrm{~g}$ at $4{ }^{\circ} \mathrm{C}$ for $10 \mathrm{~min}$. The supernatant was collected and added slowly into $40 \mathrm{~mL}$ of frozen ice in $250 \mathrm{~mL}$ beaker, on ice. Sodium bicarbonate powder was added slowly into solution over ice until pH at 67. The solution was transferred into separatory funnel $(250 \mathrm{~mL})$, and $100 \mathrm{~mL}$ of chloroform was added into separatory funnel, followed by agitation 5-10 times. The funnel was kept stationary after agitation until two distinct layers were formed. The peracetylated oligomannosides-containing chloroform-rich bottom layer was collected under fume hood. Another $100 \mathrm{~mL}$ of chloroform was added into separatory funnel for further agitation and extraction. Two bottom layers were pooled together and transferred into separatory funnel again. $20 \mathrm{~mL}$ of saturated sodium bicarbonate solution (in water) was added into funnel, then stirred and the bottom layer was collected. The chloroform was removed by rotary evaporator. The dried peracetylated oligomannosides was re-dissolved in $50 \mathrm{~mL}$ of methanol and $50 \mathrm{~mL}$ of $0.2 \mathrm{M}$ sodium hydroxide and stirred at $4{ }^{\circ} \mathrm{C}$ for $90 \mathrm{~min}$ for deacetylation. The solution was concentrated until $10 \mathrm{~mL}$ by rotary evaporator. The concentrated solution was loaded into $A G^{\circledR}$ Dowex $50 \mathrm{~W}$-X8 column (bed volume $50 \mathrm{~mL}, 25-50$ mesh ion exchange resin, Bio-Rad, No.1421421) to remove excess sodium salts. All the eluates were collected, followed by concentration until $5 \mathrm{~mL}$ by rotary evaporator. For separation of oligomannosides, Bio-Gel P6 gel filtration column (80 cm long, $2 \mathrm{~cm}$ diameter, Bio-Rad, No.1504130) was prepared. The oligosaccharides fraction was loaded into column, and water was used as eluent. All the eluates were collected and separated to 3 fractions, called oligo F1, oligo F2, oligo F3. 
The methods to purify soluble glucans fractions were adapted from the methodologies developed by Manners et al. and Sugawara et al. to study $\beta$-glucans (Manners, Masson, \& Patterson, 1973; Sugawara, Takahashi, Osumi, \& Ohno, 2004). The pellet from yeast product treated with hot citrate buffer, as described previously in section 2.2 , was solubilized in $1 \mathrm{~L}$ of $1 \mathrm{~N} \mathrm{NaOH}$, stirred at room temperature overnight to hydrolyze the proteins, lipids and residual mannan. The pellet was collected by centrifugation at $8400 \mathrm{~g}$ at $4{ }^{\circ} \mathrm{C}$ for $30 \mathrm{~min}$. The pellet was washed by $1 \mathrm{~L}$ of water followed by centrifugation at $8400 \mathrm{~g}$ at $4{ }^{\circ} \mathrm{C}$ for $30 \mathrm{~min}$, extracted by $800 \mathrm{~mL}$ of $0.5 \mathrm{~N}$ acetic acid and stirred at $90{ }^{\circ} \mathrm{C}$ for $3 \mathrm{~h}$ under chemical hood. After $3 \mathrm{~h}$, solution was cooled down and centrifuged at $8400 \mathrm{~g}$ at $4^{\circ} \mathrm{C}$, for $20 \mathrm{~min}$. The pellet was extracted again by $800 \mathrm{~mL}$ of $0.5 \mathrm{~N}$ acetic acid and stirred at $90^{\circ} \mathrm{C}$ for $3 \mathrm{~h}$ and centrifuged at $8400 \mathrm{~g}$ at $4^{\circ} \mathrm{C}$, for $20 \mathrm{~min}$. The two supernatants were pooled into the same flask. The extraction of the pellet was repeated at least 5 times. The pellet was used for phosphorylation as described in section 2.5. All the supernatants were pooled together, neutralized by $\mathrm{NaOH}$ and concentrated by rotary evaporator down to $500 \mathrm{~mL}$. This soluble fraction was put into dialysis membrane (MWCO 3500) and dialyzed against 5-10 L of water at $4{ }^{\circ} \mathrm{C}$, overnight. This dialyzed fraction was collected and concentrated down to $5 \mathrm{~mL}$ by rotary evaporator.

This soluble glucan fraction was further purified by hydrophilic-lipophilic-balanced cartridge (HBL, Waters Oasis $\left.{ }^{\circledR}\right)$. The soluble polysaccharides were not bound onto this reverse-phase cartridge and all the impurities containing lipids and peptides/proteins were retained on the HLB cartridge. The cartridge was equilibrated by $5 \mathrm{~mL}$ of acetonitrile and $5 \mathrm{~mL}$ of $0.5 \mathrm{~N}$ acetic acid in a stepwise manner. This glucan fraction was loaded into HLB cartridge and eluted by $5 \mathrm{~mL}$ of $0.5 \mathrm{~N}$ acetic acid. The collected flow through was dialyzed in dialysis tube (MWCO 3500) against $2 \mathrm{~L}$ of water at $4{ }^{\circ} \mathrm{C}$, overnight and lyophilized.

\subsection{Phosphorylation of insoluble $\beta 3$-glucan}

The pellet from hot acetic acid extraction was dialyzed into dialysis membrane (MWCO 3500) against $1 \mathrm{~L}$ of water at $4{ }^{\circ} \mathrm{C}$, overnight and lyophilized. This fraction contains $\beta 3$-glucan, which was identified by linkage analysis and NMR analysis. To solubilize this fraction, phosphorylating $\beta 3$-glucan was used 
(Williams et al., 1991). 0.4g urea solubilized in $5 \mathrm{~mL}$ of dimethyl sulfoxide (DMSO) were added into the beaker containing $100 \mathrm{mg} \beta 3$-glucan then stirred until it dissolved. $1 \mathrm{~mL}$ of $85 \% \mathrm{H}_{3} \mathrm{PO}_{4}$ was added and stirred at $100^{\circ} \mathrm{C}$ for $6 \mathrm{~h}$. After cooling down, $100 \mathrm{~mL}$ of water was added and the product was filtered through $1.2 \mu \mathrm{m}$ membrane. The filtered solution contains phosphorylated $\beta 3$-glucan that was dialyzed against water, followed by lyophilization.

\subsection{NMR Analysis}

All NMR data were acquired on Avance II Bruker spectrometer equipped with BBO or TBI 5mm probe resonating at $400 \mathrm{MHz}$ for ${ }^{1} \mathrm{H}, 100.6 \mathrm{MHz}$ for ${ }^{13} \mathrm{C}$ and $162 \mathrm{MHz}$ for ${ }^{31} \mathrm{P}$. Mannan and $\beta 6$-glucan-glycogenmannan polysaccharides were dissolved in $500 \mu \mathrm{L} \mathrm{D}_{2} \mathrm{O}\left(99.96 \%{ }^{2} \mathrm{H}\right.$, Eurisotop $\left.{ }^{\circledR}\right)$ at $10 \mathrm{mg} / \mathrm{mL}$. $\beta 3$ glucan was dissolved in d6-DMSO $\left(99.96 \%{ }^{2} \mathrm{H}\right.$, Eurisotop $\left.{ }^{\circledR}\right)$ with or without $\mathrm{D}_{2} \mathrm{O}$, at $10 \mathrm{mg} / \mathrm{mL}$. The solubilized polysaccharides were then transferred into $5 \mathrm{~mm}$ Shigemi tubes (Allision Park, USA). NMR experiments were performed at $293 \mathrm{~K}$ for mannan, $341 \mathrm{~K}$ for $\beta 6$-glucan-glycogen-mannan, $353 \mathrm{~K}$ for $\beta 3$ glucan. The signals corresponding to methyl group of acetone $\left(\delta^{1} \mathrm{H} 2.225\right.$ and $\delta^{13} \mathrm{C} 31.55 \mathrm{ppm}$.) or signals corresponding to methyl group of DMSO at $\delta^{1} \mathrm{H} 2.52$ and $\delta^{13} \mathrm{C} 40.98 \mathrm{ppm}$ were used as to calibrate the spectra. The ${ }^{1} \mathrm{H} /{ }^{1} \mathrm{H}$-COSY, ${ }^{1} \mathrm{H} /{ }^{1} \mathrm{H}$-TOCSY, ${ }^{1} \mathrm{H} /{ }^{13} \mathrm{C}-\mathrm{HSOC}$ experiments were performed by using the Bruker standard sequences and optimized for each experiment.

\subsection{Bacterial strain and intestinal epithelial cell line}

The ampicillin/erythromycin-resistant AIEC strain LF82 was isolated from an ileal biopsy specimen of a CD patient. Bacterial strain was conserved at $-80^{\circ} \mathrm{C}$ in glycerol stocks. Bacteria were seeded from the LF82 glycerol stock to Luria Bertani (LB, Conda, Madrid, Spain) broth and grown overnight at $37^{\circ} \mathrm{C}$ without shaking. The growth was spectrophotometrically evaluated at $600 \mathrm{~nm}$.

The human intestinal epithelial T84 cell line was obtained from the American Type Culture Collection (ATCC ${ }^{\circledast}$ CCL248 $^{\mathrm{TM}}$ ) and stored in liquid nitrogen. T84 cells were cultured in Dulbecco's Modified Eagle Medium: Nutrient mixture F-12 (DMEM/F12, Gibco) supplemented with 2 mM L-Glutamine (Gibco), 0.1M 
HEPES buffer (Dominique Dutscher, Brumath, France), 10\% fetal bovine serum (FBS, Dominique Dutscher, Brumath, France), and antibiotics-antimycotics to a final concentration of $100 \mathrm{U} / \mathrm{mL}$ penicillin $\mathrm{G}, 100$ $\mu \mathrm{g} / \mathrm{mL}$ streptomycin and $0.25 \mu \mathrm{g} / \mathrm{mL}$ of amphotericin B (GE Healthcare Österreich, Austria). Cells were incubated at $37^{\circ} \mathrm{C}$ in a humidified $5 \% \mathrm{CO}_{2}$ atmosphere.

2.8 Adhesion assays on AIEC LF82-infected intestinal epithelial cells in the presence of yeast glycoconjugates

T84 cells were seeded at $1.5 \times 10^{5}$ cells per well in 48 -well plates and incubated for $48 \mathrm{~h}$ at $37^{\circ} \mathrm{C}$. Before infection, monolayers were washed 3 times with phosphate buffer saline (PBS, Gibco) and culture medium was replaced by cell medium without antibiotics/antimycotics. LF82 bacterial suspension was prepared at a concentration of $1.2 \times 10^{7} \mathrm{CFU} / \mathrm{mL}$ in cell culture medium. Bacteria were incubated for $1 \mathrm{~h}$ at room temperature with increasing concentrations of yeast glycoconjugates on an orbital agitator (ratio1:1; final bacterial concentration $6 \times 10^{6} \mathrm{CFU} / \mathrm{ml}$ ). Intestinal epithelial cells were infected with bacteria/yeast product mixtures for $3 \mathrm{~h}$ at $37^{\circ} \mathrm{C}$ in a humidified $5 \% \mathrm{CO}_{2}$ atmosphere at a multiplicity of infection of 10 bacteria per cell. T84 cells were washed 3 times with phosphate buffer (PBS) and lysed with $1 \%$ Triton X100 (Sigma) in deionized water. After appropriate dilutions in physiological water, adhering bacteria were plated on Luria-Bertani agar medium and were incubated overnight at $37^{\circ} \mathrm{C}$ to determine the number of colony-forming units (CFU). The average adhesion rates (from at least 3-4 independent experiments) were expressed as a percentage of residual adhesion, which is the ratio of the bacterial adhesion level in the presence of yeast products and the adhesion level in absence of treatment (considered as $100 \%$ ). The error bars correspond to the standard error at mean or SEM.

\subsection{Animals}

Mice were housed in specific-pathogen-free conditions $\left(21-22^{\circ} \mathrm{C}, 12: 12-\mathrm{h}\right.$ light-dark cycle), with access to food and water ad libitum, in the animal facility of the University Clermont Auvergne (unité de stabulation et d'expérimentation animale, Clermont-Ferrand, France). SPF FVB/N wildtype female mice 
purchased from Charles Rivers Laboratories (France) and FVB/N CEABAC10 transgenic male mice (heterozygous, (Chan \& Stanners, 2004)) were coupled to obtain 50\% WT mice and 50\% CEABAC10 mice. This study was carried out in strict accordance with the recommendations of the Guide for the Care and Use of Laboratory Animals of the University of Clermont Auvergne (Clermont-Ferrand, France). The animal protocol was approved by the Committee for Research and Ethical Issues of the Department of Auvergne (CEMEA Auvergne; Permit Number: CEMEAA, 20160111171036870).

\subsection{Mice infection protocol and AIEC LF82 gut colonization assessment}

Eight-week-old CEABAC10 heterozygous male mice (body weight, 24-26 g) were orally pretreated with $5 \mathrm{mg}$ per day (in $0.2 \mathrm{~mL}$ of PBS, phosphate buffer saline) of the soluble glucan fraction extracted from YCW CNCM I-5268 or with PBS for non-treated mice, from day-7 to the day of the bacterial challenge (day 0). After infection, soluble glucan was administered twice a day until day 4 post-infection. Mice received $0.5 \%$ of dextran sulfate sodium (DSS, MP Biomedicals, Illkirch, France) in drinking water from day-3 to day 4 and they were treated per os with $5 \mathrm{mg}$ of streptomycin (Sigma-Aldrich) at day-1 in order to disrupt normal resident bacterial intestinal microbiota and induce a low-grade inflammation. An overnight bacterial culture of AIEC LF82 strain was harvested by centrifugation at $5500 \mathrm{~g}$ for $10 \mathrm{~min}$. The bacterial pellet was resuspended in PBS to reach a concentration of $2.5 \times 10^{10}$ bacteria $/ \mathrm{mL}$. Mice were challenged with $5 \times 10^{9}$ LF82 (in $0.2 \mathrm{~mL}$ ) at day 0 immediately after an oral administration of $0.1 \mathrm{~mL}$ of sodium bicarbonate at 0.2M (Sigma-Aldrich). Body weight was monitored throughout the experiments. At days 1, 2, 3 and 4 post-infection, fresh fecal pellets $(\approx 100 \mathrm{mg})$ were collected from individual mice and resuspended in PBS. After appropriate serial dilutions, bacteria were enumerated by plating on LuriaBertani agar medium containing $100 \mu \mathrm{g} / \mathrm{ml}$ ampicillin (Sigma-Aldrich) and $20 \mu \mathrm{g} / \mathrm{ml}$ erythromycin (SigmaAldrich) to isolate AIEC LF82 and incubated at $37^{\circ} \mathrm{C}$ overnight. The severity of colitis was assessed by the disease activity index (DAI) score, which ranges from 0 (healthy) to 12 (high activity of colitis) (Sivignon, Yan, et al., 2015). At day 4 post-infection, they were anesthetized with isoflurane and killed by cervical 
dislocation. Colon specimens were collected to quantify LF82-associated to the tissue by plating onto antibiotic-selective culture medium for LF82.

\subsection{Fecal lipocalin-2 assay}

Fecal samples from days 2 and 3 post-infection were homogenized and centrifuged at 10,000 g for $10 \mathrm{~min}$. Lipocalin-2 levels were assessed in the supernatant with the Mouse Lipocalin-2/NGAL DuoSet Kit (R\&D Systems, Minneapolis, MN, USA) according to the manufacturer's instructions. Results are expressed as $\mathrm{ng} / \mathrm{g}$ of feces.

\subsection{Statistical analysis}

Statistical analyses were performed with GraphPad Prism 6.0 (GraphPad, La Jolla, CA, USA) software package for PC. Data are expressed as means \pm standard error of the mean (SEM) or as medians. Data were compared by Student's t-test analysis (Mann-Whitney test if not parametric), or ANOVA followed by a post-Bonferroni (Kruskal-Wallis if not parametric). A $p$ value of less than 0.05 was considered to be statistically significant. ${ }^{*} p<0.05 ; * * \leq 0.01 ; * * p \leq 0.001$.

\section{Results}

\subsection{Purification of glycoconjugates from Saccharomyces cerevisiae yeasts}

The yeast cell wall is a multilayered structure that provides physical protection and osmotic support to the cell. The outer layer consists of heavily glycosylated mannoproteins collectively referred as phosphopeptido-mannans (PPM) or mannan, glycogen-like $\alpha 1$,4-glucan, and cell wall proteins that are covalently linked or associated with the inner layer made of $\beta 1,3$-glucan-chitin network and $\beta 1,6$-glucans (Klis, Mol, Hellingwerf, \& Brul, 2002) (Figure 1A). Initially, five yeast samples were chosen as starting material in order to compare their structures and activities, including three strains of intact dry yeasts (CNCM I-3856, LV04, LV08), and two yeast cell wall (YCW) enriched fractions generated by autolysis of yeasts (YCW CNCM I-3856 and YCW CNCM I-5268). Herein an experimental procedure aimed at purifying individual 
glycoconjugate fractions from the chosen whole yeasts and yeast cell walls, including PPM, $\beta 3$-glucan, $\beta 6$ glucan, and $\alpha 4$-glucan, was optimized in order to subsequently assay their capacity to inhibit bacterial adhesion (Figure 1B). In brief, crude PPM fraction was solubilized from whole yeast or YCW in citrate buffer at $120^{\circ} \mathrm{C}$, and enriched by Fehling method through the formation of insoluble copper-mannose complex (Kocourek \& Ballou, 1969). Then, remaining insoluble fraction was treated with successive chemical extractions in order to purify different types of glycoconjugates (Aklujkar, Sankh, \& Arvindekar, 2008; Manners, Masson, \& Patterson, 1973; Sugawara et al., 2004). Herein, hot diluted acetic acid was finally utilized to separate insoluble $\beta 3$-glucan from soluble $\beta 6$-glucan and $\alpha 4$-glucan fractions.

A

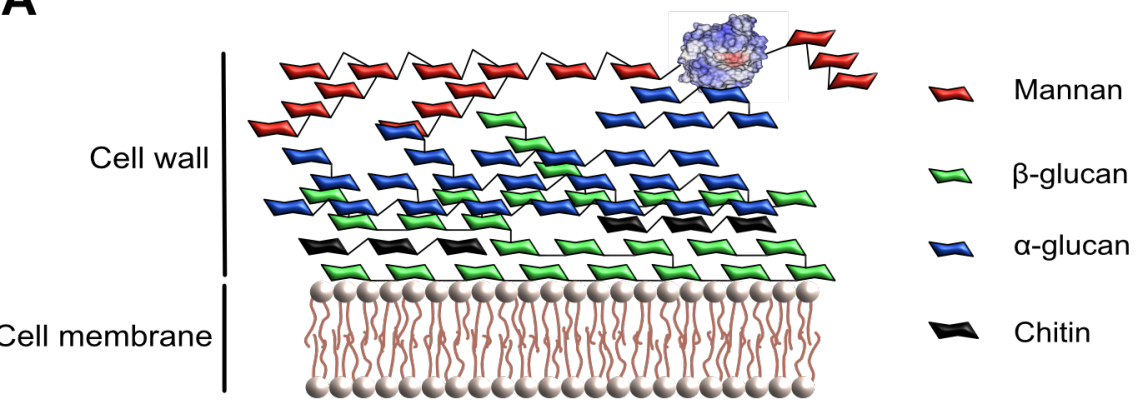

B

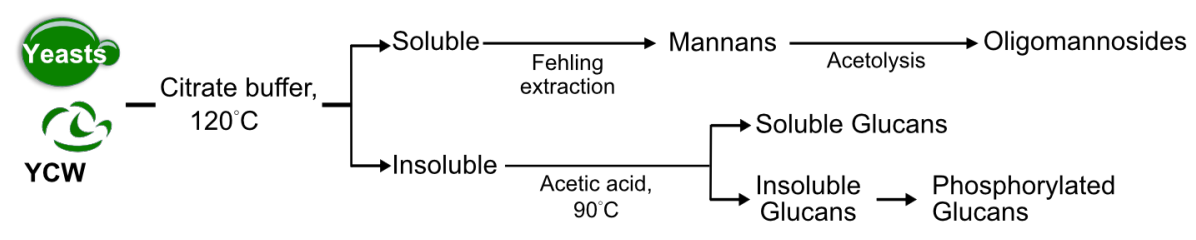

Figure 1. (A) Schematic representation of major glycoconjugates on the cell wall of S. cerevisiae. (B) Flowchart of polysaccharide extractions from intact yeasts or yeast cell walls (YCW) isolated from S. cerevisiae by autolysis. The overall fractionation pipeline was adapted from existing methodologies developped to purify mannans and $\beta$-glucans (Kocourek \& Ballou, 1969; Manners, Masson, \& Patterson, 1973; Sugawara et al., 2004).

\subsection{PPM from CNCM I-3856 yeast strain exhibits good anti-adhesive property in vitro}

The outmost layer PPM consists of polymannosylated $\mathrm{N}$-glycans covalently attached to proteins. In S. cerevisiae, the polymannosides are composed of a long stretch of $(\alpha-1,6)$-linked D-mannopyranose units substituted in $\mathrm{C} 2$ positions by short side chains of $(\alpha-1,2)$-linked mannose units that may be further 
capped by terminal Man $(\alpha-1,3)$ residues. So called acid-labile mannan domain is further attached to the ( $\alpha-1,2)$-oligomannosides through phospho-di-ester bond (Nelson, Shibata, Podzorski, \& Herron, 1991). PPM fractions from different $S$. cerevisiae strains were extracted to identify their structures and examine their inhibitory activity effects on the AIEC LF82 adhesion to T84 intestinal epithelial cells.

The structures of PPM from the five samples were characterized by a combination of NMR experiments including 1D-- ${ }^{1} \mathrm{H}-\mathrm{NMR},{ }^{1} \mathrm{H}_{-}{ }^{1} \mathrm{H}$ COSY-NMR and ${ }^{1} \mathrm{H}_{-}{ }^{13} \mathrm{C}$ HSQC-NMR analyses, based on the known structural features and NMR parameters of S. cerevisiae polymannosylated glycans (Dulary et al., 2018; Vinogradov, Petersen, \& Bock, 1998). Here, the analysis was focused on the main structural features of the polymannosylated moiety (mannan) such as the nature, the density and the terminal capping of mannosylated side chains. The anomeric region (5.5-4.8 ppm) of $1 \mathrm{D}-{ }^{1} \mathrm{H}-\mathrm{NMR}$ spectra shows five broad signals annotated as I, II, III, IV, V corresponding to five different epitopes, which are internal -2)Man( $\alpha$ 1,2) residues (I); terminal $\operatorname{Man}(\alpha-1,3)$ residues (II); -2,6)Man( $\alpha-1,6)$ branched residues (III); terminal $\operatorname{Man}(\alpha-1,2)$ and -3$) \operatorname{Man}(\alpha-1,2)$ residues (IV); unbranched -6$) \operatorname{Man}(\alpha-1,6)$ residues (V), respectively (Figure 2A, 2B). The identity of these signals was confirmed according to their ${ }^{1} \mathrm{H}_{-}{ }^{13} \mathrm{C}$ NMR parameters as established by ${ }^{1} \mathrm{H}-{ }^{13} \mathrm{C}$ HSQC experiments (Supplementary Figure 1, Supplementary table 1 ) and to the partial spin systems of the associated monosaccharides as established by ${ }^{1} \mathrm{H}-{ }^{1} \mathrm{H}$ COSY experiments (data not shown). Altogether, all five PPMs expressed complete sets of I-V NMR signals, except LV08 that was totally devoid of terminal $\operatorname{Man}(\alpha-1,3)$ residues, as shown by the absence of signal II. However, the relative quantification of individual signals showed that all five PPMs dispatched similar but slightly different mannose patterns (Supplementary Figure 1B). Among those, PPM extracted from whole yeast CNCM I3856 and from YCW CNCM I-3856 showed very similar structures according to NMR data, which indicates that prior sub-fractionation of whole yeast does not modify the nature of extracted mannans. It is noteworthy that mannans from both CNCM I-3856 samples and from LV04 strain are characterized by a higher branching level than the two other strains, as shown by the very low intensity of signal V. Intriguingly, as already mentioned, whereas the LV08 mannan does not present $\alpha 3$ mannose capping, LV04 mannan contains more $\alpha 3$ mannose capping than the four other PPM samples, accordingly to the relatively very high intensity of signal II (Figure $\mathbf{2 A}$, Supplementary Fig $\mathbf{1 B}$ ). Altogether, the five PPMs 
could be categorized in four different groups according to the combination of structural features of their mannan moieties, as depicted in Figure $\mathbf{2 C}$.

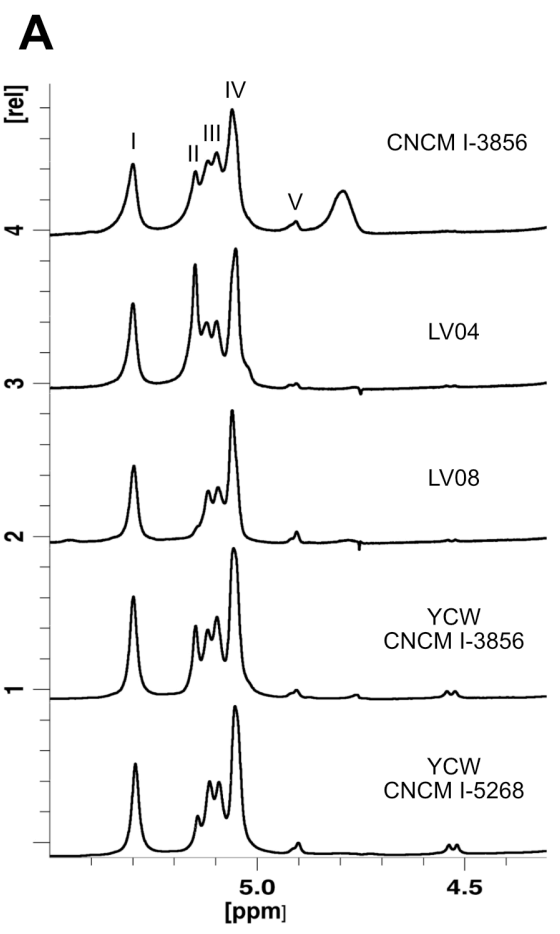

B

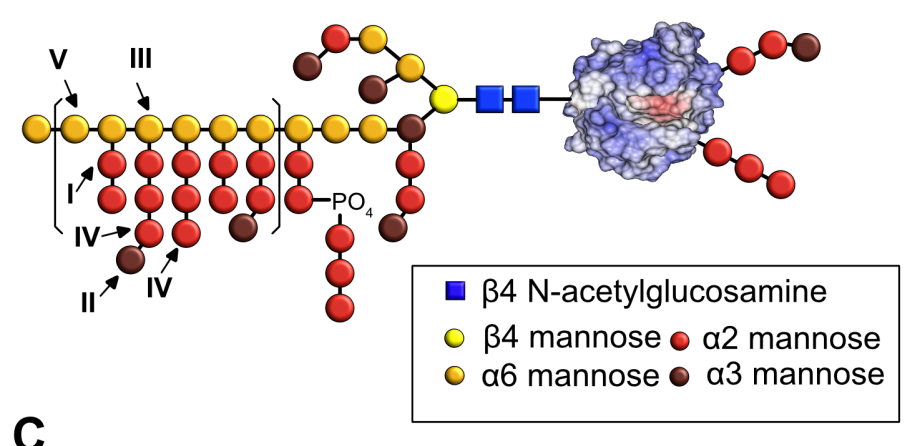

C

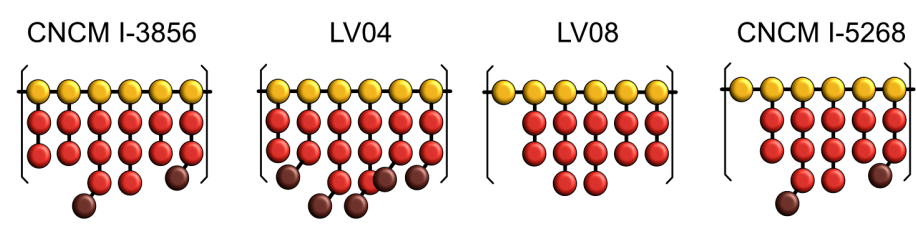

Figure 2. Structural characterizations of mannan fractions extracted from CNCM I-3856, LV04, LV08

yeasts and yeast cell walls from CNCM I-3856 and CNCM I-5268. (A) 1D- ${ }^{1} \mathrm{H}-\mathrm{NMR}$ analyses of mannan (acquisition at $400 \mathrm{MHz}, \mathrm{D}_{2} \mathrm{O}, 300 \mathrm{~K}$ ). (B) Schematic representation of PPM. (C) Schematic representation of mannan moieties from four different strains.

The capacity of five PPMs extracted from yeasts and yeast cell walls (Figure $\mathbf{3 A}$ ) to inhibit bacterial adhesion was assessed in vitro. Different concentrations of PPM were pre-incubated with AIEC LF82 bacterial strain. The glycoconjugates/bacteria mixtures were then added onto T84 cells and cellassociated LF82 bacteria were quantified in order to determine the residual adhesion percentage related to the yeast treatment. Among these, PPM from CNCM I-3856 yeast exerted the highest anti-adhesive effect for LF82 adherent to T84 cells in a dose-dependent manner (Figure 3B). Indeed, at $0.25 \mathrm{mg} / \mathrm{mL}$, PPM of CNCM I-3856 inhibited 50.06\% of bacterial adhesion, whereas a 4-fold higher concentration was needed for PPM from LV04 and LV08 strains to reach the same efficiency. Intriguingly, inhibition efficiency of CNCM I-3856 is decreasing when PPM were extracted from YCW. At the maximal concentration of 1 
$\mathrm{mg} / \mathrm{mL}$, PPM from YCW CNCM I-3856 led to an AIEC LF82 residual adhesion level of $54.64 \%$ compare to 22.87\% for PPM from whole CNCM I-3856 (Figure 3B and 3C). PPM from YCW CNCM I-3856 was less efficient to decrease AIEC LF82 attachment to cells that the one extracted from the whole yeast. Maximal inhibitory effect of PPM fraction from YCW CNCM I-5268 was slightly better than PPM from YCW CNCM $\mathrm{I}-3856$ with $46.23 \%$ of residual adhesion at concentration of $1 \mathrm{mg} / \mathrm{mL}$ (Figure $3 \mathrm{C}$ ). Altogether, combined structural and in vitro analyses showed that all PPMs exhibited anti-adhesive activities toward AIEC LF82, although with different efficiencies. The PPM activity level could not be unambiguously correlated with a specific trait such as terminal capping, which suggests that inhibitory efficiency may be dependent on other factors such as epitope presentation or density that cannot be evaluated by the used methodologies.

A
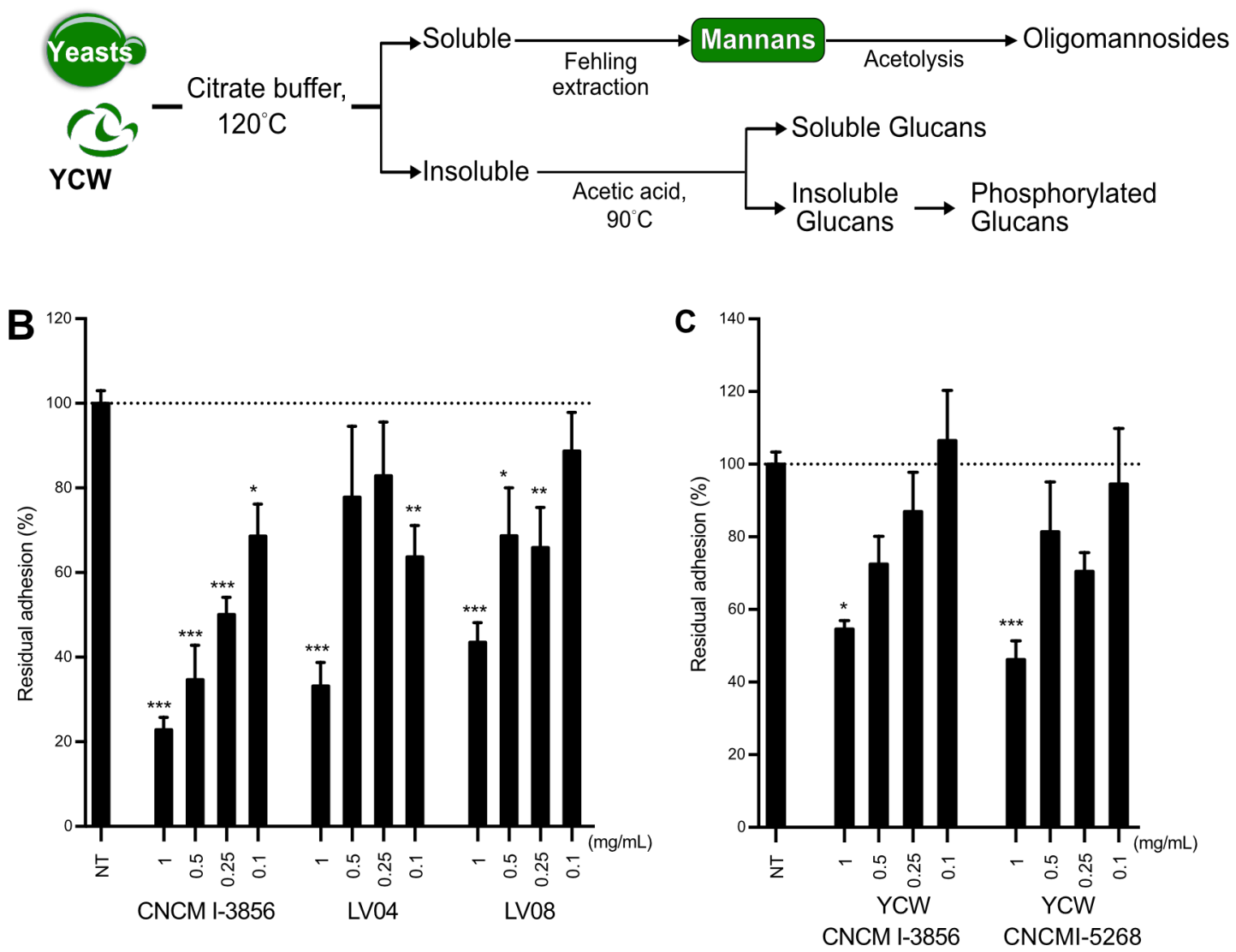

Figure 3. Mannan fractions extracted from CNCM I-3856, LV04, LV08 yeasts and CNCM I-3856, CNCM I5268 yeast cell walls reduce AIEC adhesion to T84 cells. The fraction containing phosphopeptidomannan (PPM), which was utilized for inhibition assay, was highlighted in (A). Adhesion assays: infection of T84 cells with AIEC LF82 bacteria at a multiplicity of infection of 10 bacteria/cell for 3 hours. Bacteria were 
pre-incubated 1 hour with different concentrations (in mg/mL) of PPM from CNCM I-3856, LV04, LV08 yeasts in (B), and from CNCM I-3856 and CNCM I-5268 YCWs (C), before adhesion assay. Results are expressed as percentages of adherent bacteria, LF82 infection in absence of treatment was considered as $100 \%$ (mean \pm SEM). ${ }^{*} p<0.05 ;{ }^{* *} p<0.01 ;{ }^{* * *} p<0.001$ in comparison with the non-treated condition. One-way ANOVA with Dunnett's Multiple Comparison Test.

\subsection{The production of oligomannosides from PPM does not potentiate anti-adhesive activity}

In order to determine the region of mannan that plays the role of inhibition and possibly enhance the anti-adhesive potency of the purified fractions, mannans were chemically degraded in order to generate defined sets of oligomannosylated compounds. PPM was subjected to mild acetolysis that preferentially

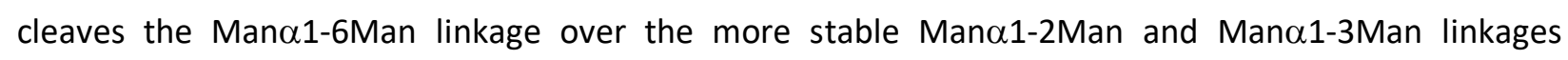
(Kocourek \& Ballou, 1969; Stewart \& Ballou, 1968), and then, the generated oligosaccharides were separated by gel filtration. Three major fractions F1-F3 were collected (Figure 4A). MALDI-MS profiles (Supplementary Figure 2) of these three fractions showed that fraction 1, which is the earliest eluting

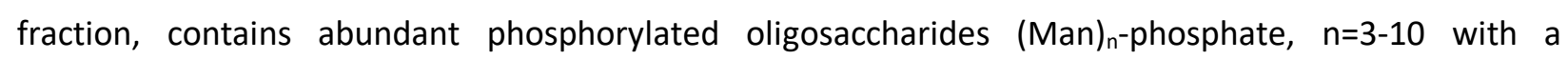
prevalence for low molecular mass oligosaccharides $\mathrm{Man}_{3}-\mathrm{PO}_{3}$ and $\mathrm{Man}_{4}-\mathrm{PO}_{3}$. Early elution of phosphorylated oligosaccharides, irrespectively of their low mass range, is due to the negative charges repulsion between phosphate groups and remnant acidic groups on the polyacrylamide medium, as

previously observed (Garenaux et al., 2008). F2 contains a mixture of smaller phosphorylated oligomannoses $\mathrm{Man}_{3}-\mathrm{PO}_{3}$ and $\mathrm{Man}_{4}-\mathrm{PO}_{3}$ as well as two groups of neutral oligosaccharides with higher degree of polymerization: one group of oligomannoses $\mathrm{Hex}_{2}$ to $\mathrm{Hex}_{9}$ and one group of oligosaccharides corresponding to $\mathrm{HexNAc}_{2} \mathrm{Hex}_{4}$ to $\mathrm{HexNAc}_{2} \mathrm{Hex}_{6}$. The monosaccharide composition strongly suggests that it is composed of the trimannosylated core $\mathrm{N}$-glycans $\left(\mathrm{GlCNAc}_{2} \mathrm{Man}_{3}\right)$ further extended by a variable number of mannose residues. Finally, F3 contains smaller oligomannoses Hex 2 to Hex 8 dominated by $\operatorname{Man}_{2}, \operatorname{Man}_{3}$ and Man 4 . 
These three fractions (F1, F2 and F3) of oligosaccharides significantly decreased LF82 adhesion to T84 cells at the concentration of $1 \mathrm{mg} / \mathrm{mL}$, but this effect did not match the inhibition efficiency of the intact PPM at the same concentration (Figure 4B). Altogether, the complex and branched structure of the mannan from CNCM I-3856 is the best inhibitor against LF82 bacterial adhesion.

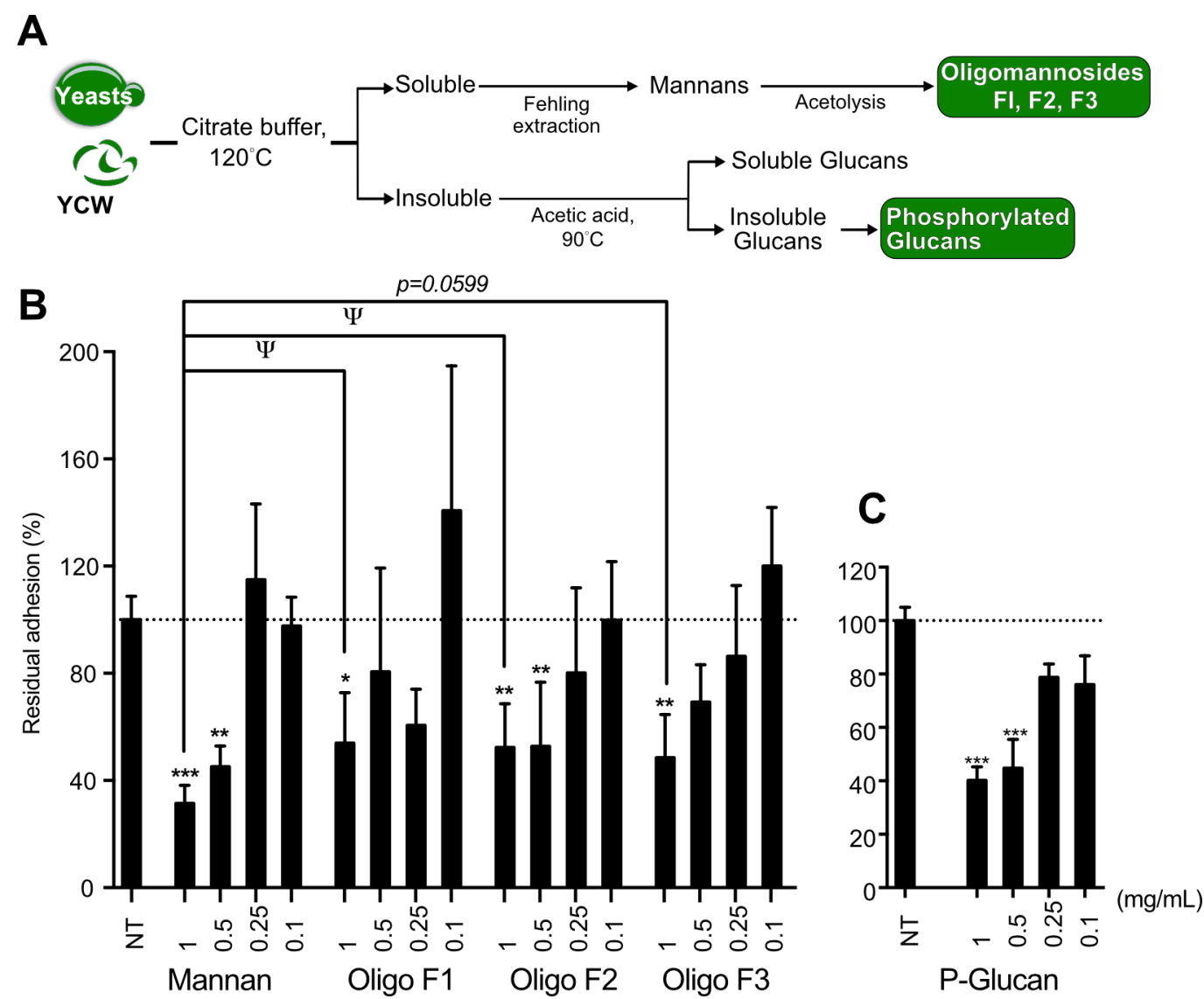

Figure 4 Activity of mannan-derived oligomannosides and phosphorylated $\beta 3$-glucan from CNCM I-3856 yeast on AIEC LF82 bacteria adhering to T84 cells. Two different fractions utilized for inhibition assay were highlighted in (A). Oligo F1, F2, F3 are different fractions of oligomannosides, which were generated from mannans by acetolysis and gel filtration. P-Glucans are soluble phosphorylated $\beta 3$-glucan that are otherwise insoluble. Adhesion assays: infection of T84 cells with AIEC LF82 bacteria at a multiplicity of infection of 10 bacteria/cell for 3 hours. Bacteria were pre-incubated 1 hour with different concentrations (in $\mathrm{mg} / \mathrm{mL}$ ) of oligomannosides and phosphorylated $\beta 3$-glucan before adhesion assay. (B) Residual adhesion after incubation with mannan and the three major fractions (F1, F2 and F3) of acetolyzed mannan. (C) Residual adhesion after incubation with phosphorylated $\beta 3$-glucan. Results are expressed as percentages of adherent bacteria, LF82 infection in absence of treatment was considered as $100 \%$ 
(mean \pm SEM). ${ }^{*} p<0.05 ;{ }^{* *} p<0.01 ; * * * p 0.001$ in comparison with the non-treated condition. $\Psi p<0.05$ between $1 \mathrm{mg} / \mathrm{mL}$ conditions. One-way ANOVA with Dunnett's Multiple Comparison Test.

\subsection{Phosphorylated $\beta 3$-glucan from CNCM I-3856 has an intermediate anti-adhesive effect in vitro}

B3-glucans were purified from the three intact yeast strains (CNCM I-3856, LV04 and LV08) and from YCW CNCM I-5268. According to the purification protocol, GC-MS composition analysis confirmed that these fractions were composed by more than $95 \%$ of glucose (GIc) and less than $5 \%$ of mannose. Overall, structural analysis showed that all four fractions were essentially similar. In particular, GC-MS analysis of partially methylated acetylated alditols (PMAA) showed a majority of 3-linked Glc residues and 3,6-linked Glc residues, in accordance with the presence of a $\beta 3$-glucan polymer further substituted in $\mathrm{C} 6$ position (Supplementary Figure 3). In addition, minor signals associated to 6-linked Glc suggests the presence of either 6-linked side chains or $\beta 6$-glucan.

Considering the structural similarity of all purified $\beta 3$-glucans, only $\beta 3$-glucan isolated from CNCM I3856 was used to conduct in vitro assay to examine the inhibiting activity toward AIEC attachment on intestinal cells. However, because of its insolubility, $\beta 3$-glucan could not be used straightly for in vitro assays. Therefore, $\beta 3$-glucan from CNCM I-3856 was phosphorylated in order to solubilize it prior to assay (Du, Zhang, Wang, \& Xiao, 2012; Shi, Shi, \& Li, 2014; Williams et al., 1991). Presence of phosphorylated glucan was first confirmed by observing a strong signal at 0 ppm on $1 \mathrm{D}^{31} \mathrm{P}-\mathrm{NMR}$ (Supplementary Figure 4A). ${ }^{1} \mathrm{H}-{ }^{31} \mathrm{P}-\mathrm{HSQC}$ NMR analysis established that the phosphate groups were in majority associated to the $\mathrm{C} 6$ positions of 3-linked as well as $\mathrm{C} 2$ and $\mathrm{C} 4$ position of 6 -linked of $\beta$-Glc residues (Supplementary Figure 4B). Then, linkage analyses by GC-MS of phosphorylated $\beta 3$-glucan (Supplementary Figure 4C) from CNCM I-3856 showed an increase in the proportions of terminal Glc and 6-linked Glc counterbalanced by a decrease in the proportion of 3-linked Glc, compared to original $\beta 3$-glucan (Supplementary Figure 3). ${ }^{1} \mathrm{H}^{13} \mathrm{C}-\mathrm{HSQC}$ NMR analysis of this fraction also confirmed that the phosphorylated $\beta 3$-glucan was made of equivalent proportions of 3-linked and 6-linked glucans (Supplementary Figure 4D, Supplementary table 2). These results indicated that phosphorylated $\beta 3$ - 
glucan fraction is constituted by shorter chains of $\beta 3$-glucan compared with the original $\beta 3$-glucan. It may be caused by the high temperature phosphoric acid that partially depolymerized the $\beta 3$-glucan polysaccharides. Of interest, even the small proportion of mannose in phosphorylated $\beta 3$-glucan fraction (5\%) compared to PPM fraction from CNCM I-3856 (92\%) (known by monosaccharide analysis, data not shown), this fraction was able to inhibit $60 \%$ of bacterial adhesion at $1 \mathrm{mg} / \mathrm{mL}$ (Figure $4 \mathrm{C}$ ).

3.5 Soluble glucan fraction exert a better anti-adhesive effect when extracted from yeast cell wall rather than intact yeast

According to the purification scheme, citrate-insoluble fraction of whole yeasts (CNCM I-3856, LV04, LV08) and of YCW (CNCM I-3856 and CNCM I-5268) treated by hot diluted acetic acid solution generates a soluble glucan fraction (Figure 1B). This soluble glucan fraction was supposedly constituted of a mixture of $\beta 6$-glucan and $\alpha 4$-glucan (Arvindekar \& Patil, 2002; Bacon, Farmer, Jones, \& Taylor, 1969; Manners, Masson, \& Patterson, 1973; Manners, Masson, Patterson, Bjorndal, \& Lindberg, 1973). In agreement to this hypothesis, $1 \mathrm{D}-{ }^{1} \mathrm{H}-\mathrm{NMR}$ spectra of the glucan soluble fractions isolated from the five yeast samples showed intense signals at $4.3 \mathrm{ppm}$ and at $5.37 \mathrm{ppm}$ tentatively attributed to internal $\beta 6$-linked glucose residues and to $\alpha 4$-linked glucose residues, respectively (Figure $\mathbf{5 A}$ ). Their attribution was further confirmed by ${ }^{1} \mathrm{H}_{-}{ }^{13} \mathrm{C}$ HSQC NMR experiments. These two monosaccharides were predominant in soluble glucan fractions isolated from CNCM I-3856, LV04 and LV08 as they represented from 82\% (CNCM I-3856) to $96 \%$ (LV08) of the total signal intensities of anomeric protons. Unexpectedly, NMR analysis of soluble glucan fractions isolated from yeast cell walls (YCW CNCM I-3856 and YCW CNCM I-5268) showed an additional set of intense ${ }^{1} \mathrm{H}$ signals previously identified as $\alpha$-Man residues signals I to $\mathrm{V}$ associated to mannan (Figure 2), which established the presence of significant quantities of mannan in these two samples (Figure 5A). The nature of these signals was further confirmed by ${ }^{1} \mathrm{H}_{-}{ }^{13} \mathrm{C}$ HSQC NMR analyses (Figure 5B, Supplementary table 3). This set of signals could also be observed in the soluble fractions extracted from CNCM I-3856, LV04 and LV08, but with much lower intensity. The proportions of $\beta$-glucan, $\alpha$-glucan and mannan (expressed as $\beta$-glucan/ $\alpha$-glucan/mannan ratios, GGM) in the soluble glucan fractions isolated from each sample were estimated by area integration of individual signals detected by 
1D- ${ }^{1} \mathrm{H}-\mathrm{NMR}$ analyses (Supplementary Figure 5). The soluble glucan fraction isolated from CNCM I-3856, LV04 and LV08 were characterized by very high proportions of $\alpha$-glucan (from 56 to $88 \%$ ) and low proportions of mannan (from 2 to 18\%), as depicted on Figure 5C. On the contrary, soluble glucan fractions from YCW CNCM I-3856 and YCW CNCM I-5268 contain a high content of both $\beta$-glucan and mannan but low content of $\alpha$-glucan with GGM index around 40:15:45 (Supplementary Figure 5). The high mannose content of soluble glucan fraction extracted from yeast cell wall was confirmed by GC-MS monosaccharide and linkage analyses (Supplementary Figure 6). Thus, these results demonstrated that when the soluble glucan fraction is purified from whole yeasts (CNCM I-3856, LV04 and LV08), it is almost mainly constituted by $\alpha$-glucan whereas the soluble glucan fraction is highly enriched in $\beta$-glucan and mannan when it is purified from cell walls.

A

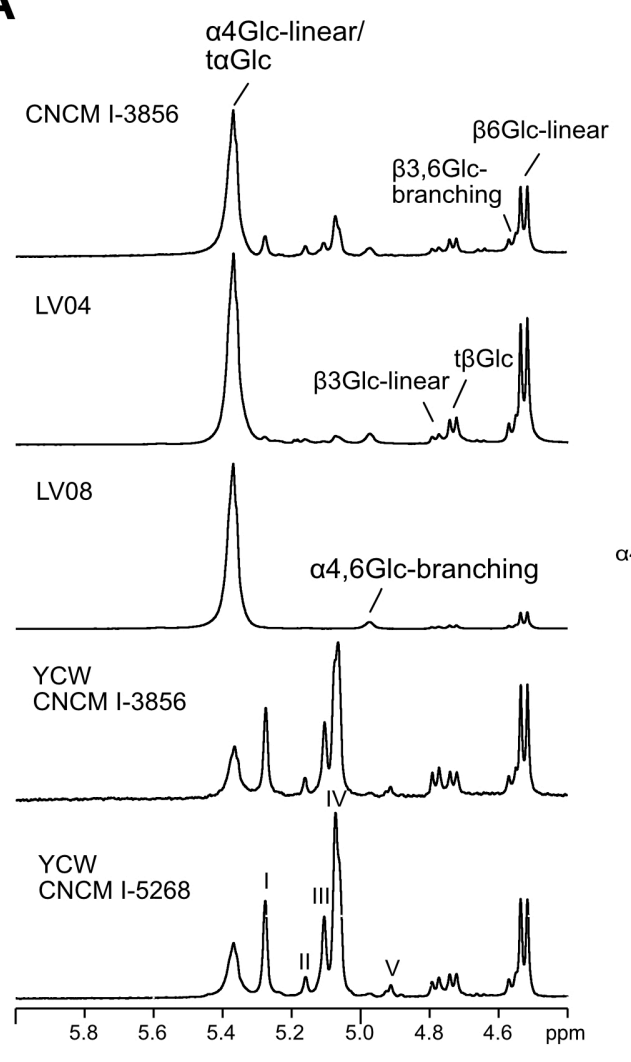

B

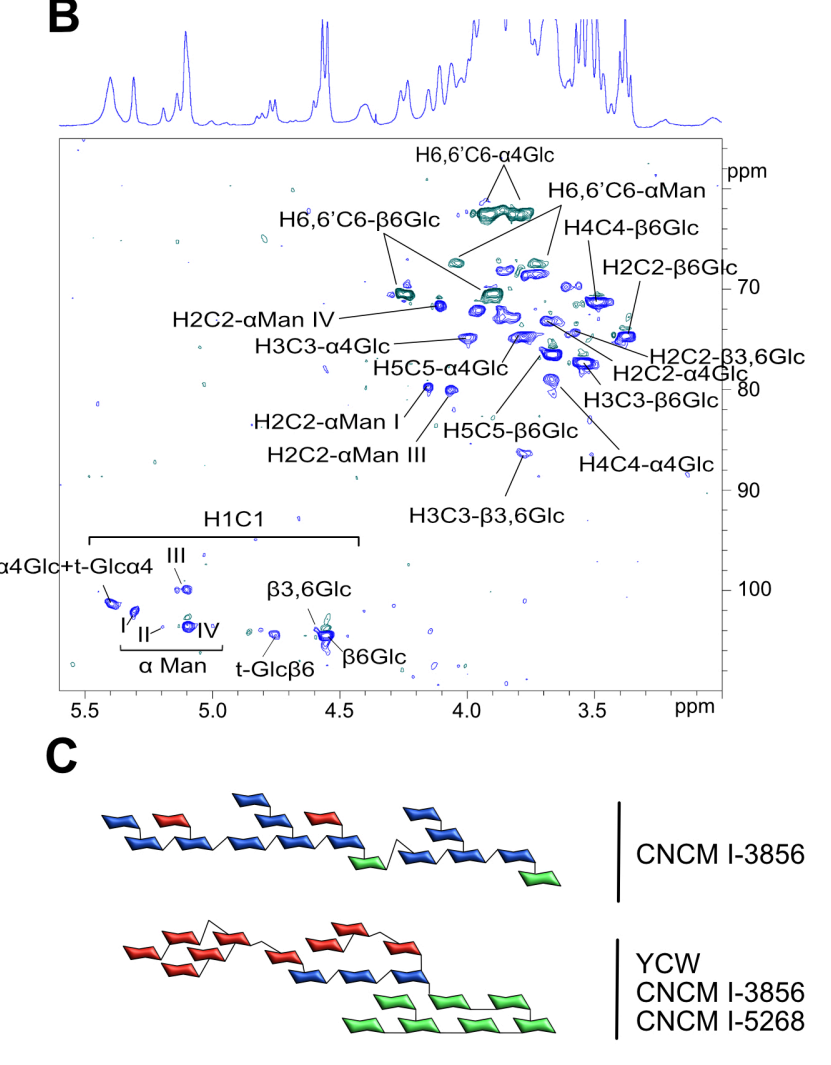

Figure 5. Structural characterizations of soluble glucan fractions extracted from CNCM I-3856, LV04,

LV08 yeasts and CNCM I-3856, CNCM I-5268 yeast cell walls. (A) $1 \mathrm{D}-{ }^{1} \mathrm{H}-\mathrm{NMR}$ analyses of glucans (acquisition at $400 \mathrm{MHz}, \mathrm{D}_{2} \mathrm{O}, 341 \mathrm{~K}$., Signals annotated as peaks I, II, III, IV, V are the signals corresponding to mannan as shown in Figure3. (B) ${ }^{1} \mathrm{H}-{ }^{13} \mathrm{C}$ HSQC spectrum (C) Schematic 
representation and proportions of heteropolymers consisting in mannan (red), $\alpha$-glucan (blue) and $\beta$-glucan (green).

Considering the clear structural differences observed between soluble glucan fractions depending on the starting material (Figure 6A), their in vitro cellular activities toward bacterial adhesion were compared. In intestinal epithelial cells T84, adhesion inhibition property of the soluble glucan fraction extracted from whole yeast CNCM I-3856 was shown to be moderate with a residual adhesion level of $42.3 \%$ at the concentration of $1 \mathrm{mg} / \mathrm{mL}$ (Figure 6B). At the same concentration, soluble glucan fraction from YCW CNCM I-3856 exhibits a much higher anti-adhesive effect since it decreases LF82 adhesion at $16.7 \%$ of residual adhesion (Figure 6C). Interestingly, soluble glucan fraction from YCW CNCM I-5268 exhibited the highest inhibitory effect, as $94.3 \%$ of the bacterial adhesion to T84 cells was prevented at the concentration of $1 \mathrm{mg} / \mathrm{mL}$.

The high proportion of mannose in these fractions may be instrumental to the increased anti-adhesive activity. However, the fact that the inhibitory effect is far superior to that of the mannan fraction demonstrates that richness in mannan in not sufficient to trigger the activity. The presence of the three partners $\beta$-glucan/ $\alpha$-glucan/mannan in a precise ratio may be required to potentiate the anti-adhesive efficacy. 
A

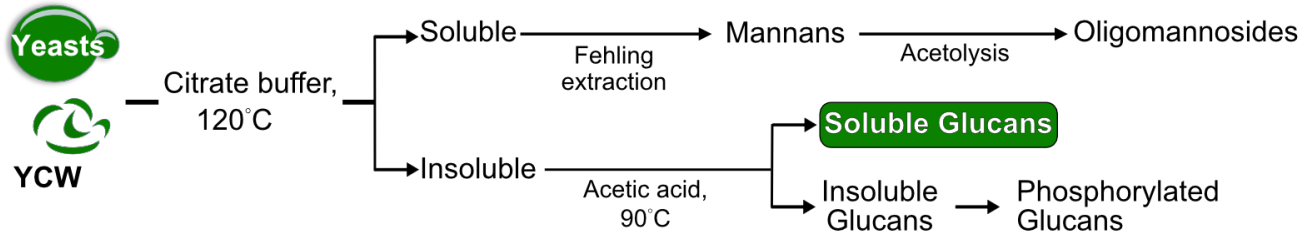

B

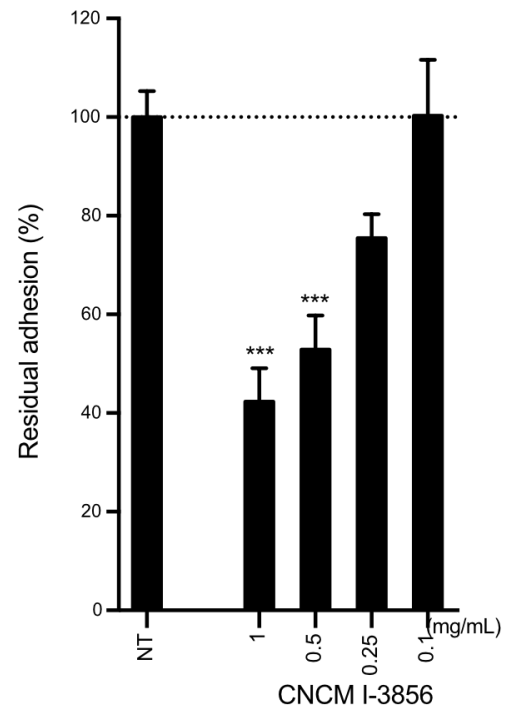

C

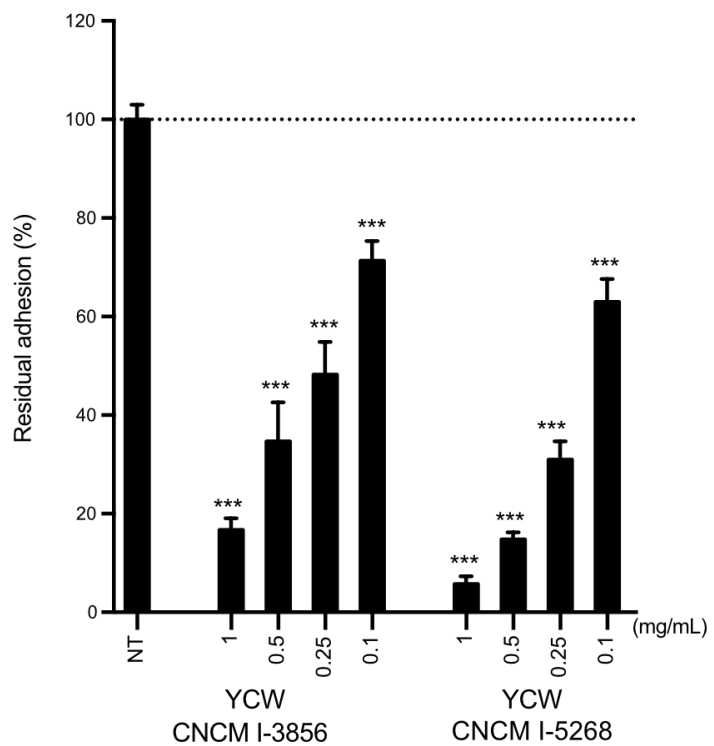

Figure 6. Soluble glucan fractions extracted from CNCM I-3856 and YCW from CNCM I-3856, CNCM I5268 strongly reduce AIEC adhesion to T84 cells. Soluble glucans were extracted according to (A). Adhesion assays: infection of T84 cells with AIEC LF82 bacteria at a multiplicity of infection of 10 bacteria/cell for 3 hours. Bacteria were pre-incubated 1 hour with different concentrations (in $\mathrm{mg} / \mathrm{mL}$ ) of soluble glucan from CNCM I-3856 yeasts (A), or from CNCM I-3856 and CNCM I-5268 YCWs (B) before adhesion assay. Results are expressed as percentages of adherent bacteria, LF82 infection in absence of treatment was considered as $100 \%$ (mean \pm SEM). ${ }^{* * *} p<0.001$ in comparison with the non-treated condition. One-way ANOVA with Dunnett's Multiple Comparison Test.

3.6 Soluble glucan fraction isolated from yeast cell wall favors the elimination of AIEC LF82 bacteria from the gut of mice

Considering the high capacity of soluble glucan fraction isolated from yeast cell wall to inhibit the bacterial adhesion to T84 cells in vitro, the in vivo activity of the most effective soluble glucan fraction isolated from YCW CNCM I-5268 was assessed in the CEABAC10 mouse model mimicking CD susceptibility 
infected with the AIEC LF82 bacterial strain. Bacterial infection induced a decrease of the body weight of mice for 48 hours. Yeast treatment succeeded in reversing the body weight curve from 2 days postinfection (dpi), and body weights were almost restored at the initial level at dpi 4 (Figure 7A). AIEC LF82 bacterial loads in the feces of mice were significantly decreased from dpi 2 to dpi 4 by the soluble $\beta$-glucan fraction treatment (Figure 7B). This result was confirmed by the analysis of the area under curve, which reflects the global colonization of the gut during the infection period for each mouse $\left(2.34 \times 10^{8}\right.$ cfu versus $2.95 \times 10^{7} \mathrm{cfu}$ for non-treated mice and treated mice respectively, Figure 7C). Yeast treatment also reduced the number of LF82 bacteria associated to the colonic mucosa. At dpi 4, $62.5 \%$ of mice still presented AIEC associated to the mucosa, whereas percentage decreased at $42.8 \%$ in the glucan-treated group (Figure 7D). A slight improvement was observed concerning the severity of colitis as assessed by the disease activity index (DAI) score (Figure 7E) and the concentration of lipocalin-2, a fecal marker of intestinal inflammation, was significantly decreased at dpi 2 (Figure 7F).

A

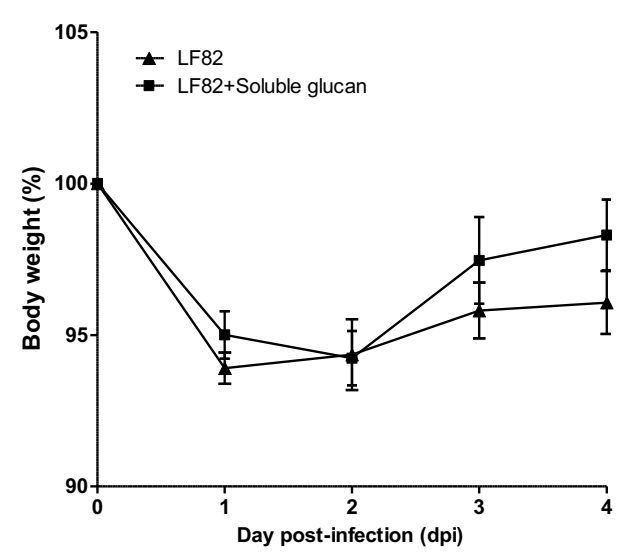

C

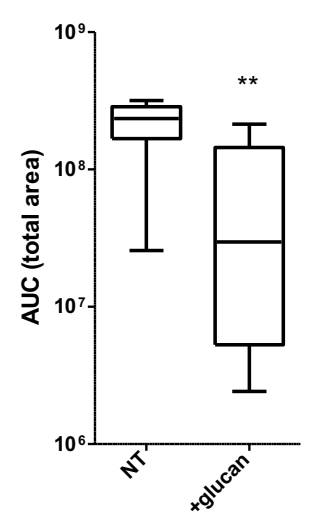

B

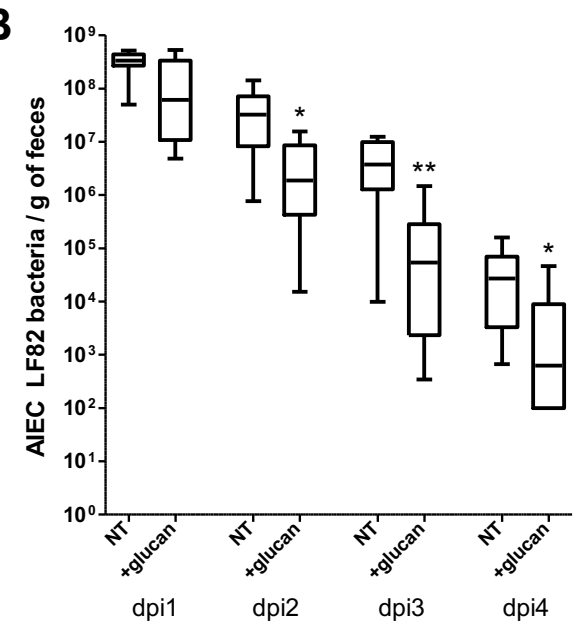

E

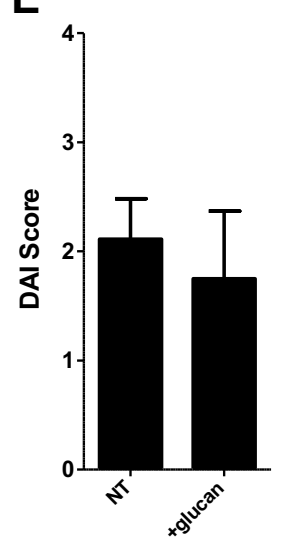

$\mathbf{F}$

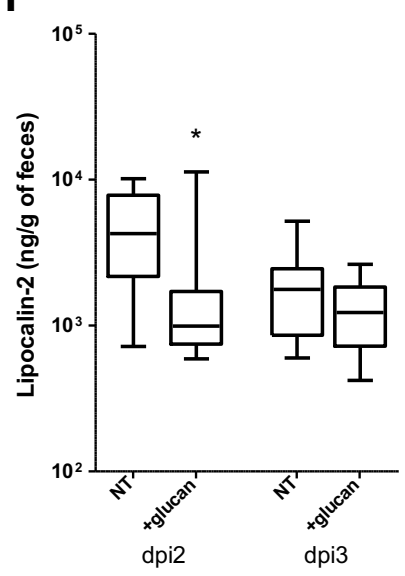


LF82 bacteria from the gut of CEABAC10 mice. (A) Body weight in percentages (means \pm sem). (B) AIEC LF82 bacterial load in the feces of mice (in bacteria per gram of feces) after oral challenge with $5 \times 10^{9}$ bacteria/mouse (box and whiskers-min to max). (C) Area under curve (total area) of AIEC LF82 colonization from dpi 1 to dpi 4 (box and whiskers-min to max). (D) AIEC LF82 bacteria associated to the colonic tissue (in bacteria per gram of tissue) at dpi 4. Each point represents bacterial quantification for one mouse, bars correspond to medians. (E) Disease activity Index (DAI) scores at dpi 3 (means \pm sem). (F) lipocalin- 2 concentrations in $\mathrm{ng} / \mathrm{g}$ of feces (box and whiskers-min to max). $n=8$ mice for non-treated (NT) group; $n=7$ for soluble glucan-treated group. Mann Whitney test, ${ }^{*} p<0.05$ $;^{* * p}<0.01$

To conclude, soluble glucan fraction extracted from YCW from CNCM I-5268 was highly effective to prevent AIEC LF82 attachment to intestinal epithelial cells, but also exerts beneficial properties in vivo in decreasing LF82 gut colonization and in reducing a fecal biomarker of intestinal inflammation, lipocalin-2. The tri-hetero partners present in soluble glucan fraction is optimal to decrease efficiently the AIEC gut colonization.

\section{Discussion}

The potential of probiotics in CD management still remains unclear as standard probiotic strategies have hitherto failed to demonstrate any clear benefits (Oka \& Sartor, 2020). Even so, Saccharomyces yeast, especially Var. boulardii CNCM I-745, has been shown to decrease risks of relapse or improve intestinal permeability in inactive CD (Garcia Vilela et al., 2008; Guslandi, Mezzi, Sorghi, \& Testoni, 2000), but these clinical data are rare and rely on relatively small groups of patients ( 32 and 25 patients for these two studies). Specific pathobiont-targeted strategies, and more precisely AIEC-targeted strategy, should be of interest to the disease management, with a requisite stratification of AIEC-carrier patients. The present work stems from the seminal observation that selected Saccharomyces cerevisiae CNCM I-3856 
strain exhibited significant ability to prevent adhesion of AIEC to intestinal epithelial cells in culture and to human ileal biopsies isolated from CD patients abnormally expressing the mannosylated protein CEACAM6 (Sivignon, de Vallee, et al., 2015). Using a preclinical model, it is shown that CNCM I-3856 significantly decreased AIEC colonization and colitis symptoms of infected transgenic mice expressing CEACAM6 (CEABAC10 model) and restored impaired barrier function of intestinal mucosa. Both the intact yeast and the S. cerevisiae cell wall derivatives administered to mice showed protective properties toward AIEC, strongly suggesting that the beneficial effect was associated with a surface component. As AIEC are known to colonize the ileal mucosa of CD patients via the interaction of the mannose-specific adhesin FimH with CEACAM6 mannosylated protein expressed on epithelial cell surface, we hypothesized that yeast polymannosylated glycoconjugates were involved in the anti-adhesive properties by competing with natural ligand of FimH. In order to identify molecular motifs responsible for the anti-adhesive properties of the yeast, the main glycoconjugates associated with yeast cell wall were sub-fractionated to individually assay their biological properties. Both intact yeast cells and yeast cell wall (YCW) preparations were used in order to uncover potential differences in the activity of non-surface expressed molecules and to potentially improve the originally observed activity. In parallel, the impact of strain-specific structural differences was evaluated with the objective of providing insights into the structure-to-function activity of the selected molecules. Based on FimH recognition specificity, we originally expected the highly mannosylated surface glycoconjugates would present the highest anti-adhesive activity. As expected, PPM isolated from all samples exhibited good in vitro anti-adhesive properties toward T84 cells. On average, PPM isolated from intact yeast showed better activities (about 20 to $40 \%$ residual adhesion) at high concentration $(1 \mathrm{mg} / \mathrm{mL}$ ) than those isolated from YCW (about 45 to $55 \%$ residual adhesion). One may speculate that pre-purification of the cell wall removes some surface components that potentiate the activity of mannan or sub-fractionates mannans with different activities. Indeed, comparative analysis showed that polymannosylated moieties of PPM from different origins exhibited variable structural features such as the extend of Mana1-3 terminal capping (Figure 2, peak II) that varies from 0 in LV08 to $20 \%$ in LV04, and the degree of Man 1 1-2 branching of the -6Man $\alpha 1$ - chain (Figure 2, peak III). However, none of these structural features could be directly correlated with the anti-adhesive activity, strongly 
suggesting that the linkage pattern of mannan has no influence on the overall activity of PPM. Similarly, depolymerization of the mannan chain into more homogenous smaller oligosaccharides did not improve the anti-adhesive activity. On the contrary, the maximum activity was decreased for all purified fractions, which strongly suggests that polymerization increasing avidity is important to reach optimal activity, as previously observed for numerous bacterial lectins, including FimH from uropathogenic $E$. coli and LecA from Pseudomonas aeruginosa (Palmioli, Sperandeo, Polissi, \& Airoldi, 2019; Sauer et al., 2019). Thus, highly purified PPMs, irrespective of their origins, did not exhibit higher anti-adhesive potential than the intact yeasts (Sivignon, de Vallee, et al., 2015) as more than $80 \%$ of inhibition in the used experimental conditions could not be reached.

Unexpectedly, the highest inhibition levels were observed with soluble glucan fractions, especially those extracted from yeast cell wall (YCW) preparations. Structural analyses revealed that soluble glucan fractions, exclusively from YCW, were enriched in mannan. This mannan was covalently attached to $\alpha$ and $\beta$-glucans according to previous works (Arvindekar \& Patil, 2002; Kollar et al., 1997; Kwiatkowski, Thielen, Glenney, \& Moran, 2009). Thus, presence of the three partners $\beta$-glucan, $\alpha$-glucan and mannan in this soluble glucan fraction with a ratio $45: 15: 40$ potentializes anti-adhesive effect, as AIEC LF82 adhesion to T84 cells was nearly abrogated. As the maximal efficiency was obtained with soluble glucans extracted from YCW CNCM I-5268, this fraction was tested in the CEABAC10 mouse model. CNCM I-5268 soluble glucans were able to accelerate AIEC elimination from mice gut, to prevent LF82 attachment to intestinal mucosa and to decrease intestinal inflammation, as demonstrates by decreased fecal lipocalin2 level.

These data demonstrate that upstream yeast processing has a direct effect on the activity of the soluble glucan fraction but the precise role of the "strain-effect" in the anti-adhesive effects should be established. Indeed, despite a similar $\beta$-glucan/ $\alpha$-glucan/mannan ratio, soluble glucans from YCW CNCM I-5268 has a superior biological activity compared to those from YCW CNCM I-3856. A hypothesis should be the ligand presentation for FimH adhesin, that is different between the two yeast strains.

\section{Conclusions}


For better inflammatory diseases management, it seems essential to develop therapies rationally designed to manipulate dysbiotic microbiota. Here, a bioactive fraction in yeast wall responsible for competitive blocking of AIEC bacteria to intestinal epithelium through FimH was identified. This soluble glucan fraction represents a promising pathobiont-targeted tool to detach AIEC from the intestinal mucosa. To demonstrate the efficacity of such therapy in CD patients, AIEC-carriage should be considered as an essential criterion of inclusion. Use of a concomitant companion diagnostic test to rapidly guide patients towards an AIEC-targeted treatment is necessary and heptyl-mannose-grafted cellulose represents a promising method to easily detect AIEC in biological fluids (Cauwel et al., 2019). It should also be interesting to propose this soluble glucan as a post-biotic strategy in patients susceptible to be colonized by AIEC, for example after surgery to limit AIEC implantation at the ileal mucosa, in order to decrease postoperative recurrence and thus to extend periods of remission. Finally, as FimH is broadly expressed by enterobacteria, this soluble glucan fraction containing $\beta$-glucan/ $\alpha$-glucan/mannan with a ratio can be applied more generally in prophylactic or therapeutic treatments against FimH-expressing bacteria responsible for gastro-intestinal acute or others chronic disorders. Administration of this bioactive yeast fraction in combination with a live probiotic yeast could be considered in order to cumulate anti-adhesive properties against FimH-producers with another beneficial effect like antiinflammatory response.

\section{Declaration of Interest}

Nathalie Ballet and Pascal Vandekerckove are full-time employed by the company Lesaffre International, Lesaffre Group, Marcq-en-Baroeul, France. All other authors declare no competing interests.

\section{Acknowledgements}

We thank Abdelkrim Alloui for animal care (unité de stabulation et d'expérimentation animale, Université Clermont Auvergne, Clermont-Ferrand, France). We are grateful to Emeline Calichon for her technical assistance and to the PAGes core facility (http://plateforme- pages.univ-lille1.fr) and UMS 2014 - US 41 - Plateformes Lilloises en Biologie \& Santé for providing the scientific and technical environment 
conducive to achieving this work. We thank Sebastian Ku from Lesaffre Singapore for English language proofreading. This study was supported by Lesaffre international, the Ministère de la Recherche et de la Technologie (Université Clermont Auvergne), Inserm (UMR 1071), INRAE (USC-2018) and by the French government IDEX-ISITE initiative 16-IDEX-0001 (CAP 20-25), I-SITE project (CAP 2025) of the University of Clermont Auvergne. 


\section{Reference}

Abraham, S. N., Sun, D., Dale, J. B., \& Beachey, E. H. (1988). Conservation of the D-mannose-adhesion protein among type 1 fimbriated members of the family Enterobacteriaceae. Nature, 336(6200), 682-684.

Agus, A., Massier, S., Darfeuille-Michaud, A., Billard, E., \& Barnich, N. (2014). Understanding hostadherent-invasive Escherichia coli interaction in Crohn's disease: opening up new therapeutic strategies. Biomed Res Int, 2014, 567929.

Aklujkar, P. P., Sankh, S. N., \& Arvindekar, A. U. (2008). A Simplified Method for the Isolation and Estimation of Cell Wall Bound Glycogen in Saccharomyces cerevisiae. Journal of the Institute of Brewing, 114(3), 205-208.

Arvindekar, A. U., \& Patil, N. B. (2002). Glycogen--a covalently linked component of the cell wall in Saccharomyces cerevisiae. Yeast, 19(2), 131-139.

Bacon, J. S., Farmer, V. C., Jones, D., \& Taylor, I. F. (1969). The glucan components of the cell wall of baker's yeast (Saccharomyces cerevisiae) considered in relation to its ultrastructure. Biochem J, 114(3), 557-567.

Barnich, N., Carvalho, F. A., Glasser, A. L., Darcha, C., Jantscheff, P., Allez, M., . . Darfeuille-Michaud, A. (2007). CEACAM6 acts as a receptor for adherent-invasive E. coli, supporting ileal mucosa colonization in Crohn disease. J Clin Invest, 117(6), 1566-1574.

Baumgart, M., Dogan, B., Rishniw, M., Weitzman, G., Bosworth, B., Yantiss, R., .. Simpson, K. W. (2007). Culture independent analysis of ileal mucosa reveals a selective increase in invasive Escherichia coli of novel phylogeny relative to depletion of Clostridiales in Crohn's disease involving the ileum. Isme J, 1(5), 403-418.

Boudeau, J., Glasser, A. L., Masseret, E., Joly, B., \& Darfeuille-Michaud, A. (1999). Invasive ability of an Escherichia coli strain isolated from the ileal mucosa of a patient with Crohn's disease. Infect Immun, 67(9), 4499-4509.

Bringer, M. A., Glasser, A. L., Tung, C. H., Meresse, S., \& Darfeuille-Michaud, A. (2006). The Crohn's disease-associated adherent-invasive Escherichia coli strain LF82 replicates in mature phagolysosomes within $\mathrm{J774}$ macrophages. Cell Microbiol, 8(3), 471-484.

Carvalho, F. A., Barnich, N., Sauvanet, P., Darcha, C., Gelot, A., \& Darfeuille-Michaud, A. (2008). Crohn's disease-associated Escherichia coli LF82 aggravates colitis in injured mouse colon via signaling by flagellin. Inflamm Bowel Dis, 14(8), 1051-1060.

Carvalho, F. A., Barnich, N., Sivignon, A., Darcha, C., Chan, C. H., Stanners, C. P., \& Darfeuille-Michaud, A. (2009). Crohn's disease adherent-invasive Escherichia coli colonize and induce strong gut inflammation in transgenic mice expressing human CEACAM. J Exp Med, 206(10), 2179-2189.

Cauwel, M., Sivignon, A., Bridot, C., Nongbe, M. C., Deniaud, D., Roubinet, B., . . Gouin, S. G. (2019). Heptylmannose-functionalized cellulose for the binding and specific detection of pathogenic $E$. coli. Chem Commun (Camb), 55(68), 10158-10161.

Chan, C. H., \& Stanners, C. P. (2004). Novel mouse model for carcinoembryonic antigen-based therapy. Mol Ther, 9(6), 775-785.

Darfeuille-Michaud, A., Neut, C., Barnich, N., Lederman, E., Di Martino, P., Desreumaux, P., ... Colombel, J. F. (1998). Presence of adherent Escherichia coli strains in ileal mucosa of patients with Crohn's disease. Gastroenterology, 115(6), 1405-1413.

De la Fuente, M., Franchi, L., Araya, D., Diaz-Jimenez, D., Olivares, M., Alvarez-Lobos, M., . . Hermoso, M. A. (2014). Escherichia coli isolates from inflammatory bowel diseases patients survive in macrophages and activate NLRP3 inflammasome. Int J Med Microbiol, 304(3-4), 384-392.

Dreux, N., Denizot, J., Martinez-Medina, M., Mellmann, A., Billig, M., Kisiela, D., . . Barnich, N. (2013). Point mutations in FimH adhesin of Crohn's disease-associated adherent-invasive Escherichia coli enhance intestinal inflammatory response. PLoS Pathog, 9(1), e1003141.

Du, L., Zhang, X., Wang, C., \& Xiao, D. (2012). Preparation of Water Soluble Yeast Glucan by Four Kinds of Solubilizing Processes. Engineering, Vol.04No.10, 5. 
Dulary, E., Yu, S. Y., Houdou, M., de Bettignies, G., Decool, V., Potelle, S., ... Foulquier, F. (2018). Investigating the function of Gdt1p in yeast Golgi glycosylation. Biochim Biophys Acta Gen Subj, 1862(3), 394-402.

Eaves-Pyles, T., Allen, C. A., Taormina, J., Swidsinski, A., Tutt, C. B., Jezek, G. E., . . Torres, A. G. (2008). Escherichia coli isolated from a Crohn's disease patient adheres, invades, and induces inflammatory responses in polarized intestinal epithelial cells. Int J Med Microbiol, 298(5-6), 397-409.

Eshdat, Y., Speth, V., \& Jann, K. (1981). Participation of pili and cell wall adhesion in the yeast agglutination activity of Escherichia coli. Infect Immun, 34(3), 980-986.

Garcia Vilela, E., De Lourdes De Abreu Ferrari, M., Oswaldo Da Gama Torres, H., Guerra Pinto, A., Carolina Carneiro Aguirre, A., Paiva Martins, F., . . Sales Da Cunha, A. (2008). Influence of Saccharomyces boulardii on the intestinal permeability of patients with Crohn's disease in remission. Scand J Gastroenterol, 43(7), 842-848.

Garenaux, E., Yu, S. Y., Florea, D., Strecker, G., Khoo, K. H., \& Guerardel, Y. (2008). A single step method for purification of sulfated oligosaccharides. Glycoconj J, 25(9), 903-915.

Gevers, D., Kugathasan, S., Denson, L. A., Vazquez-Baeza, Y., Van Treuren, W., Ren, B., . . Xavier, R. J. (2014). The treatment-naive microbiome in new-onset Crohn's disease. Cell Host Microbe, 15(3), 382-392.

Glasser, A. L., Boudeau, J., Barnich, N., Perruchot, M. H., Colombel, J. F., \& Darfeuille-Michaud, A. (2001). Adherent invasive Escherichia coli strains from patients with Crohn's disease survive and replicate within macrophages without inducing host cell death. Infect Immun, 69(9), 5529-5537.

Guslandi, M., Mezzi, G., Sorghi, M., \& Testoni, P. A. (2000). Saccharomyces boulardii in maintenance treatment of Crohn's disease. Dig Dis Sci, 45(7), 1462-1464.

Klis, F. M., Mol, P., Hellingwerf, K., \& Brul, S. (2002). Dynamics of cell wall structure in Saccharomyces cerevisiae. FEMS Microbiol Rev, 26(3), 239-256.

Kocourek, J., \& Ballou, C. E. (1969). Method for fingerprinting yeast cell wall mannans. J Bacteriol, 100(3), 1175-1181.

Kollar, R., Reinhold, B. B., Petrakova, E., Yeh, H. J., Ashwell, G., Drgonova, J., . . Cabib, E. (1997). Architecture of the yeast cell wall. Beta(1-->6)-glucan interconnects mannoprotein, beta(1-->)3glucan, and chitin. J Biol Chem, 272(28), 17762-17775.

Kwiatkowski, S., Thielen, U., Glenney, P., \& Moran, C. (2009). A Study of Saccharomyces cerevisiae Cell Wall Glucans. Journal of the Institute of Brewing, 115(2), 151-158.

Lopez-Siles, M., Martinez-Medina, M., Busquets, D., Sabat-Mir, M., Duncan, S. H., Flint, H. J., . . G GarciaGil, L. J. (2014). Mucosa-associated Faecalibacterium prausnitzii and Escherichia coli coabundance can distinguish Irritable Bowel Syndrome and Inflammatory Bowel Disease phenotypes. Int J Med Microbiol, 304(3-4), 464-475.

Manichanh, C., Rigottier-Gois, L., Bonnaud, E., Gloux, K., Pelletier, E., Frangeul, L., . . Dore, J. (2006). Reduced diversity of faecal microbiota in Crohn's disease revealed by a metagenomic approach. Gut, 55(2), 205-211.

Manners, D. J., Masson, A. J., \& Patterson, J. C. (1973). The structure of a beta-(1 leads to 3)-D-glucan from yeast cell walls. Biochem J, 135(1), 19-30.

Manners, D. J., Masson, A. J., Patterson, J. C., Bjorndal, H., \& Lindberg, B. (1973). The structure of a beta(1--6)-D-glucan from yeast cell walls. Biochem J, 135(1), 31-36.

Martin, H. M., Campbell, B. J., Hart, C. A., Mpofu, C., Nayar, M., Singh, R., . . Rhodes, J. M. (2004). Enhanced Escherichia coli adherence and invasion in Crohn's disease and colon cancer. Gastroenterology, 127(1), 80-93.

Meconi, S., Vercellone, A., Levillain, F., Payre, B., Al Saati, T., Capilla, F., . . Altare, F. (2007). Adherentinvasive Escherichia coli isolated from Crohn's disease patients induce granulomas in vitro. Cell Microbiol, 9(5), 1252-1261.

Nelson, R. D., Shibata, N., Podzorski, R. P., \& Herron, M. J. (1991). Candida mannan: chemistry, suppression of cell-mediated immunity, and possible mechanisms of action. Clin Microbiol Rev, 4(1), 1-19. 
Oka, A., \& Sartor, R. B. (2020). Microbial-Based and Microbial-Targeted Therapies for Inflammatory Bowel Diseases. Dig Dis Sci.

Palmioli, A., Sperandeo, P., Polissi, A., \& Airoldi, C. (2019). Targeting Bacterial Biofilm: A New LecA Multivalent Ligand with Inhibitory Activity. Chembiochem, 20(23), 2911-2915.

Reed, G., \& Nagodawithana, T. W. (1991). Yeast technology.

Sauer, M. M., Jakob, R. P., Luber, T., Canonica, F., Navarra, G., Ernst, B., . . Glockshuber, R. (2019). Binding of the Bacterial Adhesin FimH to Its Natural, Multivalent High-Mannose Type Glycan Targets. J Am Chem Soc, 141(2), 936-944.

Shi, F., Shi, J., \& Li, Y. (2014). Mechanochemical phosphorylation and solubilisation of beta-D-glucan from yeast Saccharomyces cerevisiae and its biological activities. PLoS One, 9(7), e103494.

Sivignon, A., de Vallee, A., Barnich, N., Denizot, J., Darcha, C., Pignede, G., . . . Darfeuille-Michaud, A. (2015). Saccharomyces cerevisiae CNCM I-3856 prevents colitis induced by AIEC bacteria in the transgenic mouse model mimicking Crohn's disease. Inflamm Bowel Dis, 21(2), 276-286.

Sivignon, A., Yan, X., Alvarez Dorta, D., Bonnet, R., Bouckaert, J., Fleury, E., . . Barnich, N. (2015). Development of Heptylmannoside-Based Glycoconjugate Antiadhesive Compounds against Adherent-Invasive Escherichia coli Bacteria Associated with Crohn's Disease. MBio, 6(6), e0129801215.

Small, C. L., Reid-Yu, S. A., McPhee, J. B., \& Coombes, B. K. (2013). Persistent infection with Crohn's disease-associated adherent-invasive Escherichia coli leads to chronic inflammation and intestinal fibrosis. Nat Commun, 4, 1957.

Sokol, H., Brot, L., Stefanescu, C., Auzolle, C., Barnich, N., Buisson, A., . . Investigators, R. S. G. (2019). Prominence of ileal mucosa-associated microbiota to predict postoperative endoscopic recurrence in Crohn's disease. Gut.

Sommer, F., Ruhlemann, M. C., Bang, C., Hoppner, M., Rehman, A., Kaleta, C., . . Franke, A. (2017). Microbiomarkers in inflammatory bowel diseases: caveats come with caviar. Gut, 66(10), 17341738.

Stewart, T. S., \& Ballou, C. E. (1968). A comparison of yeast mannans and phosphomannans by acetolysis. Biochemistry, 7(5), 1855-1863.

Sugawara, T., Takahashi, S., Osumi, M., \& Ohno, N. (2004). Refinement of the structures of cell-wall glucans of Schizosaccharomyces pombe by chemical modification and NMR spectroscopy. Carbohydr Res, 339(13), 2255-2265.

Vinogradov, E., Petersen, B., \& Bock, K. (1998). Structural analysis of the intact polysaccharide mannan from Saccharomyces cerevisiae yeast using $1 \mathrm{H}$ and $13 \mathrm{C}$ NMR spectroscopy at $750 \mathrm{MHz}$. Carbohydr Res, 307(1-2), 177-183.

Williams, D. L., McNamee, R. B., Jones, E. L., Pretus, H. A., Ensley, H. E., Browder, I. W., \& Di Luzio, N. R. (1991). A method for the solubilization of a (1----3)-beta-D-glucan isolated from Saccharomyces cerevisiae. Carbohydr Res, 219, 203-213. 


\section{Supplementary Data}

Heteropolysaccharides from S. cerevisiae show anti-adhesive properties against $E$. coli associated with Crohn's disease

Adeline Sivignon ${ }^{a, 1}$, Shin-Yi $Y^{b, 1}$, Nathalie Ballet ${ }^{c}$, Pascal Vandekerckove ${ }^{c}$, Nicolas Barnich ${ }^{a, 2}$, Yann Guerardel $^{b, d, 2, *}$

${ }^{a}$ Université Clermont Auvergne/Inserm U1071; USC-INRAE 2018, Microbes, Intestin, Inflammation et Susceptibilité de l'Hôte (M2iSH), Clermont-Ferrand, France.

b Univ. Lille, CNRS, UMR 8576 - UGSF - Unité de Glycobiologie Structurale et Fonctionnelle, Lille, France.

' Lesaffre International, Lesaffre group, 59700, Marcq-en-Barœul, France.

d Institute for Glyco-core Research (iGCORE), Gifu University, Gifu, Japan

${ }^{1}$ These authors are co-first authors and contribute equally to this work

${ }^{2}$ These authors are co-last authors and contribute equally to this work

* corresponding author 


\section{Supplementary methods}

\section{Monosaccharide Analysis and Linkage Analysis}

For monosaccharide analysis of mannan and glucan, $100 \mu \mathrm{g}$ of inositol and $100 \mu \mathrm{g}$ of target sugars were taken and put in the same tube. $500 \mu \mathrm{L}$ of $4 \mathrm{~N}$ trifluroacetic acid (TFA) were added and incubated at 100 ${ }^{\circ} \mathrm{C}$, for $4 \mathrm{~h}$ to hydrolysis polysaccharides into monosaccharides, followed by drying the sample by under stream of nitrogen at room temperature. Reduction monosaccharides by $500 \mu \mathrm{L}$ of $20 \mathrm{mg} / \mathrm{mL} \mathrm{NaBH}$ in $2 \mathrm{~N} \mathrm{NH}_{4} \mathrm{OH}$, room temperature, overnight. The reaction was quenched by adding $500 \mu \mathrm{L}$ of $10 \%$ acetic acid in methanol, and dry under stream of nitrogen, again. Repeat 4-5 times. Then, reduced monosaccharides were peracetylated by adding $500 \mu \mathrm{L}$ of acetic anhydride, $100^{\circ} \mathrm{C}$, for $4 \mathrm{~h}$, and derivatized monosaccharides were extracted by $1 \mathrm{~mL}$ of chloroform. $1 \mathrm{~mL}$ of water was added to do water-chloroform partition to remove excess salts. Repeat 5 times extraction and dry under stream of nitrogen. The derivatized monosaccharides were re-dissolved in $500 \mu \mathrm{L}$ chloroform. $1 \mu \mathrm{L}$ of sample was injected into GC-FID (TRACE GC Ultra, Thermo Fisher Scientific). The capillary column is SOLGEL ( $30 \mathrm{~m} \times 0.25 \mathrm{~mm}, 0.25 \mu \mathrm{m}$ film thickness, SGE Analytical Science). The initial oven temperature was held at $120^{\circ} \mathrm{C}$, increased to $230^{\circ} \mathrm{C}$ at $3^{\circ} \mathrm{C} / \mathrm{min}$, and then, $270^{\circ} \mathrm{C}$ for $10 \mathrm{~min}$.

For linkage analysis of mannan and glucan, $200 \mu \mathrm{g}$ of target polysaccharides were dissolved in $100 \mu \mathrm{L}$ of DMSO. Polysaccharides were derivatized by modified(Hakomori, 1964). $33 \mathrm{mg}$ of Nal was taken in one glass tube and washed by pentane several times to remove glycerol. Nal was dried under nitrogen and the dissolved polysaccharides were added into Nal-contained glass tube, followed by addition of $100 \mu \mathrm{L}$ of $\mathrm{CH}_{3}$ l. Reaction was agitated for 10 minutes at room temperature. The reaction was quenched by adding $1 \mathrm{~mL}$ of water on ice and permethylated polysaccharides were extracted by $2 \mathrm{~mL}$ chloroform/water partition. The chloroform phase was dried under nitrogen. Samples were hydrolyzed by 4 N TFA at $100^{\circ} \mathrm{C}$, for $4 \mathrm{hr}$ and reduced by $1 \mathrm{~mL} \mathrm{NaBD} 4(20 \mathrm{mg} / \mathrm{mL})$ in $2 \mathrm{~N} \mathrm{NH}_{4}$. The reaction was quenched by $1 \mathrm{~mL}$ of $10 \%$ acetic acid in methanol. Then, sugars were peracetylated and chloroform/water extracted as described above. The derivatized monosaccharides were dissolved in $1 \mathrm{~mL}$ of chloroform and $1 \mu \mathrm{L}$ were injected into 
GC-MS (TRACE GC Ultra, Thermo Fisher Scientific). The initial oven temperature was held at $120^{\circ} \mathrm{C}$, increased to $230^{\circ} \mathrm{C}$ at $2^{\circ} \mathrm{C} / \mathrm{min}$, and then, $270^{\circ} \mathrm{C}$ for $10 \mathrm{~min}$.

\section{Mass Spectrometry Analyses}

The oligosaccharides were aliquoted for permethylation. In brief, the dried oligosaccharides in glass tube were permethylated with $\mathrm{NaOH}$ /DMSO and methyl iodide according to Ciucanu and Kerek method(Ciucanu \& Kerek, 1984) (https://doi.org/10.1016/0008-6215(84)85242-8) extracted by chloroform/water partitioning. Repeated water-chloroform partitions were used, and the sample was dried under a stream of nitrogen. The permethylated oligosaccharides were dissolved in $100 \%$ acetonitrile and pre-mixed with 2,5-dihydroxybenzoic acid matrix solution (10 mg/ml in 50\% acetonitrile/water, v/v, Sigma), then spotted on target. MS spectra were acquired by using a MALDI-TOF/TOF 4800 mass spectrometer (Applied Biosystems) equipped with Nd:YAG laser, operated in the reflectron mode. Data acquisition was normally comprised of 40 sub-spectra of 50 laser shots, and the laser energy is set 5000 5300. 


\section{Supplementary figures}

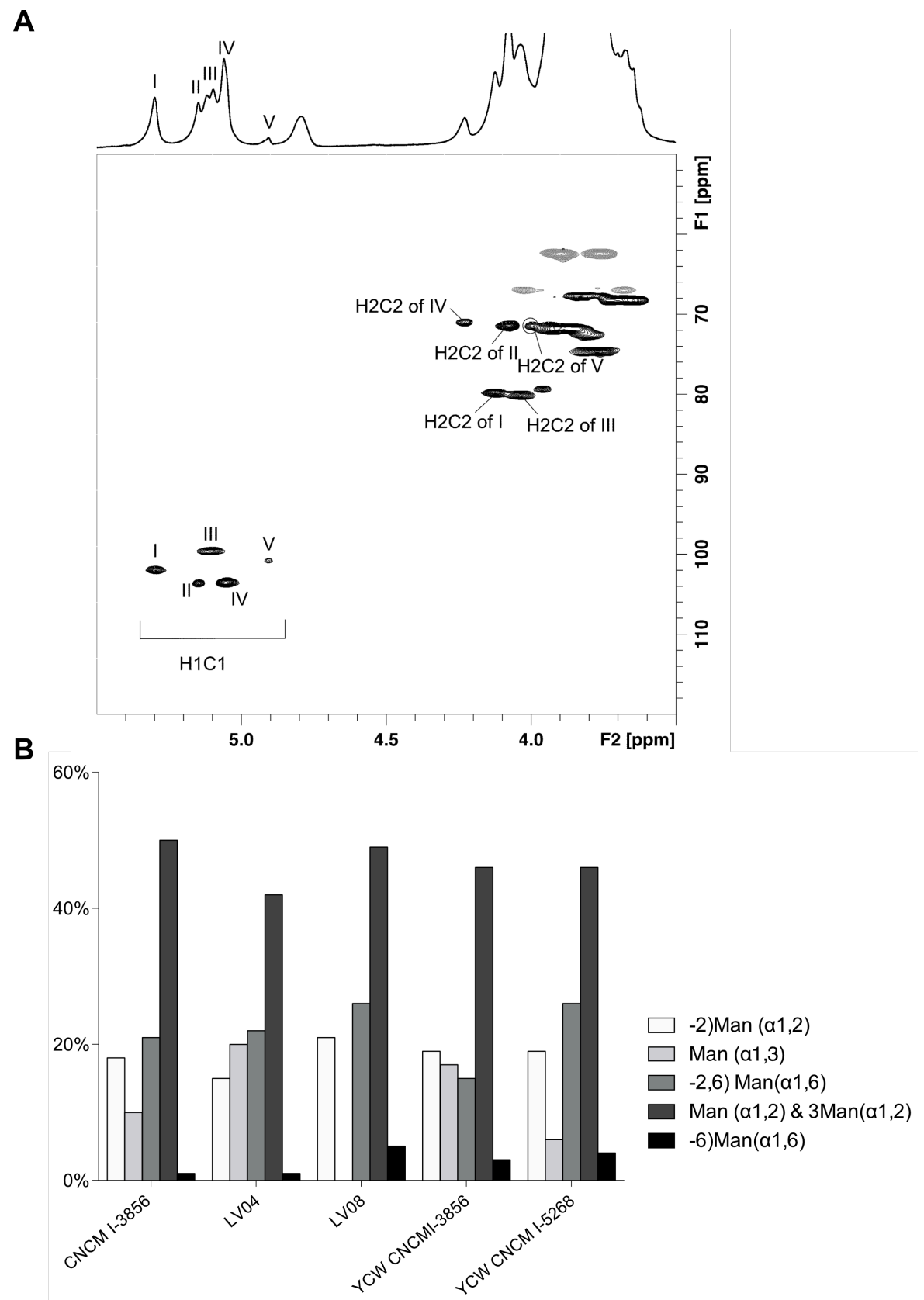

Supplementary Figure $1 .{ }^{1} \mathrm{H}-{ }^{13} \mathrm{C}$ HSQC NMR analysis of PPM extracted by CNCM I-3856 yeast (acquisition at $400 \mathrm{MHz}$ NMR, D2O, 300K). Distinct 5 signals were shown in HSQC data, which can be used for quantification of different sugar regions in one yeast strain itself and different strains. 

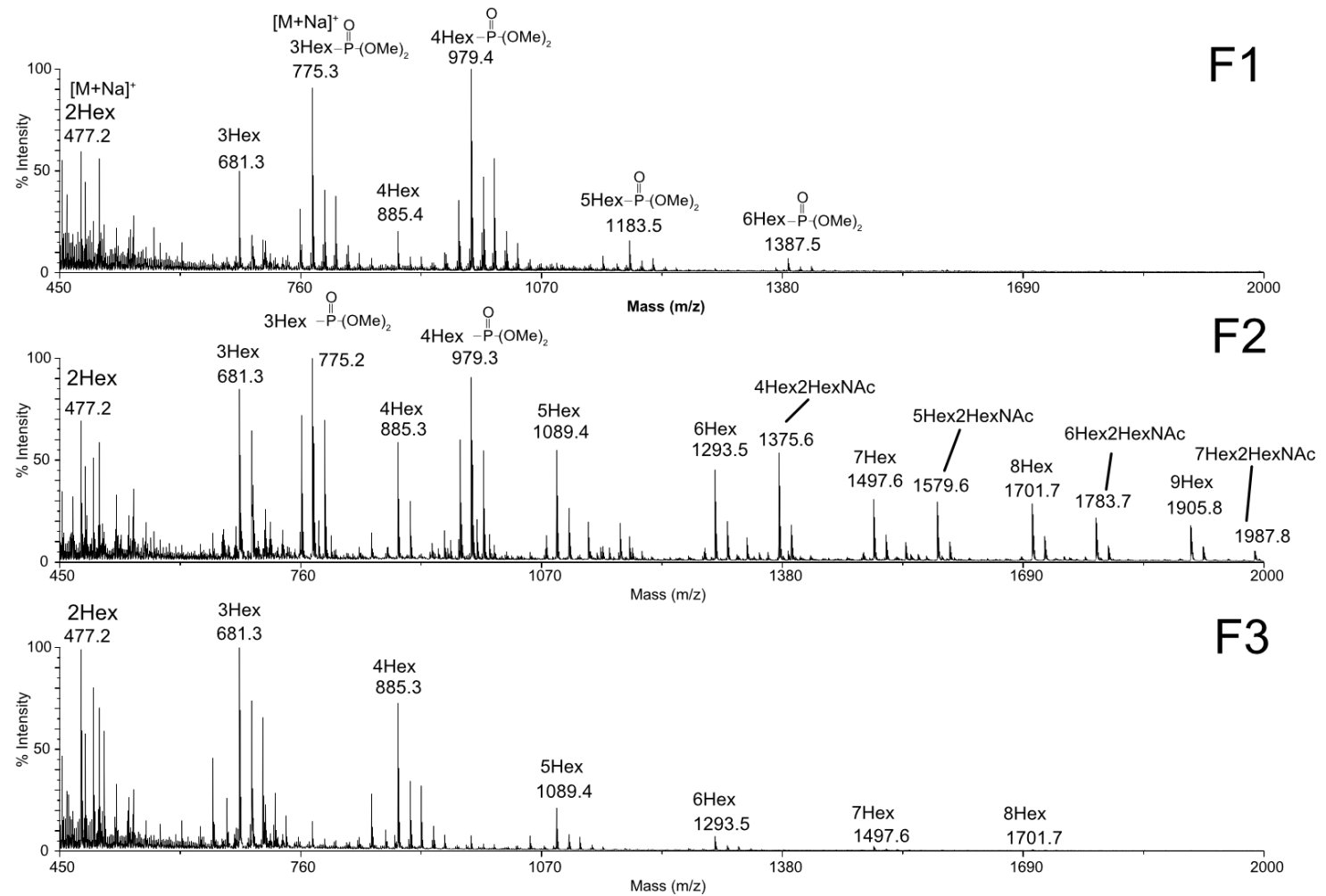

Supplementary Figure 2. Structural characterizations of three fractions containing oligomannosides separated by gel filtration. MALDI-MS analyses in the positive ion mode of permethylated oligosaccharides. 


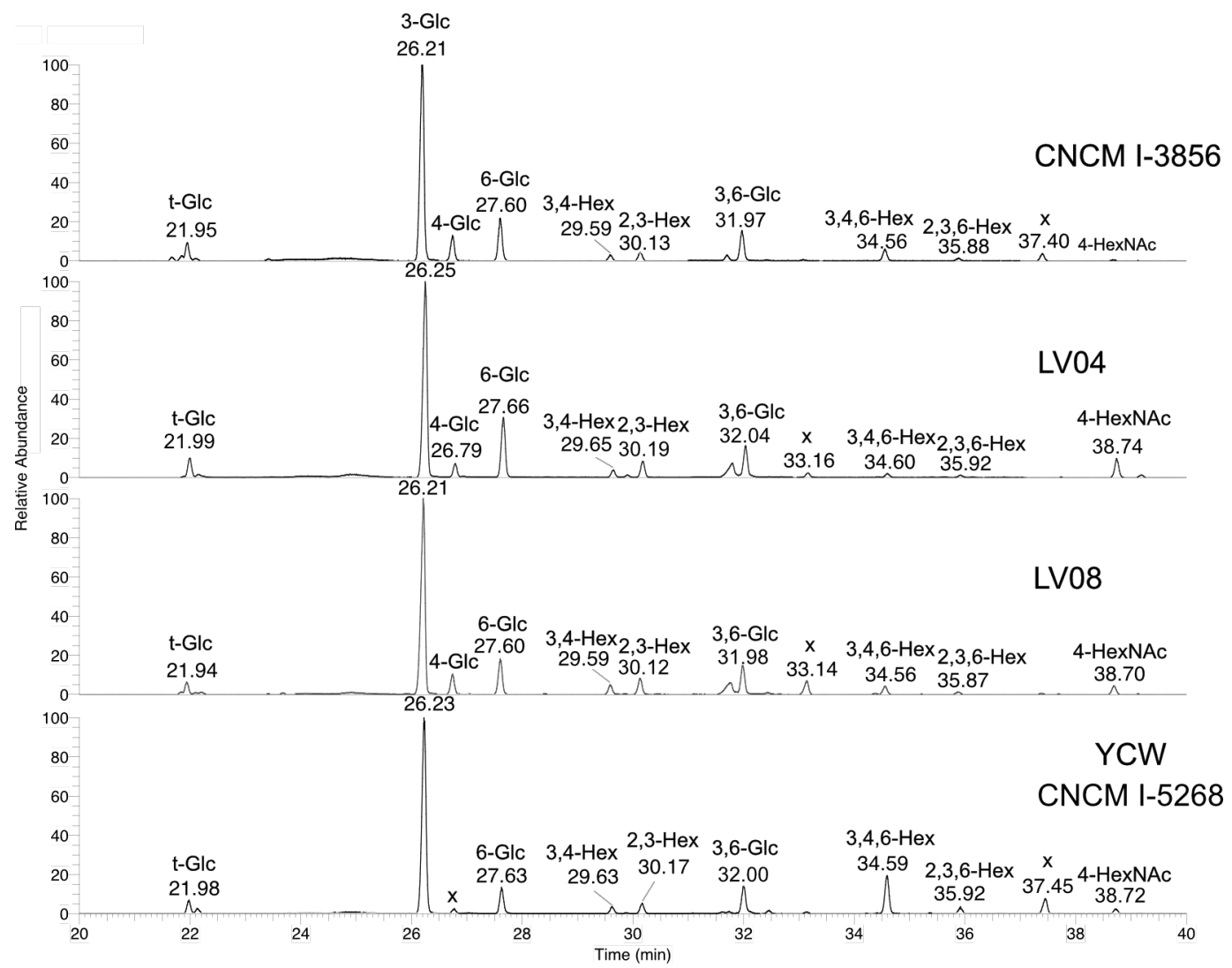

Supplementary Figure 3. Comparison of $\beta 3$-glucan fractions isolated from four different yeast preparations. Linkage analysis of $\beta 3$-glucan from different strains were established by GC-MS. As shown here, GC-MS chromatograms of four strains did not show obvious strain-specific differences. 
A

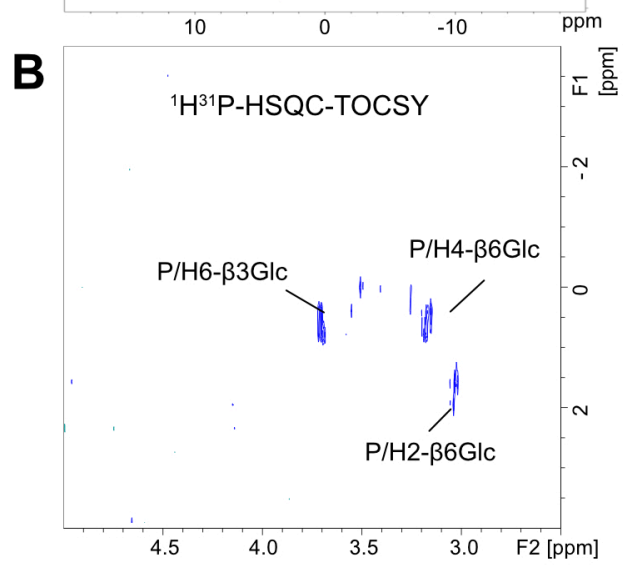

C

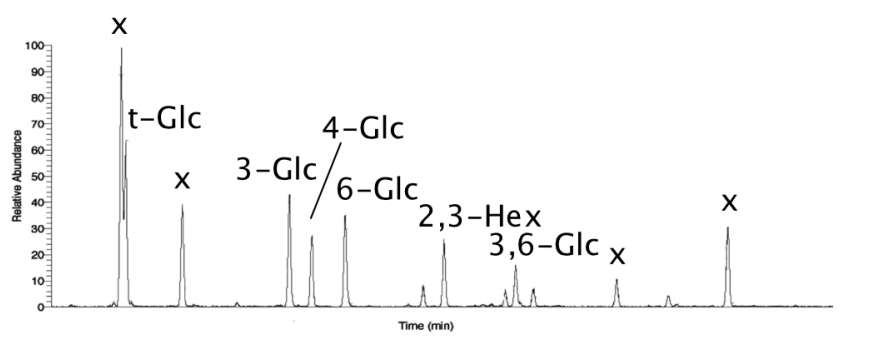

D

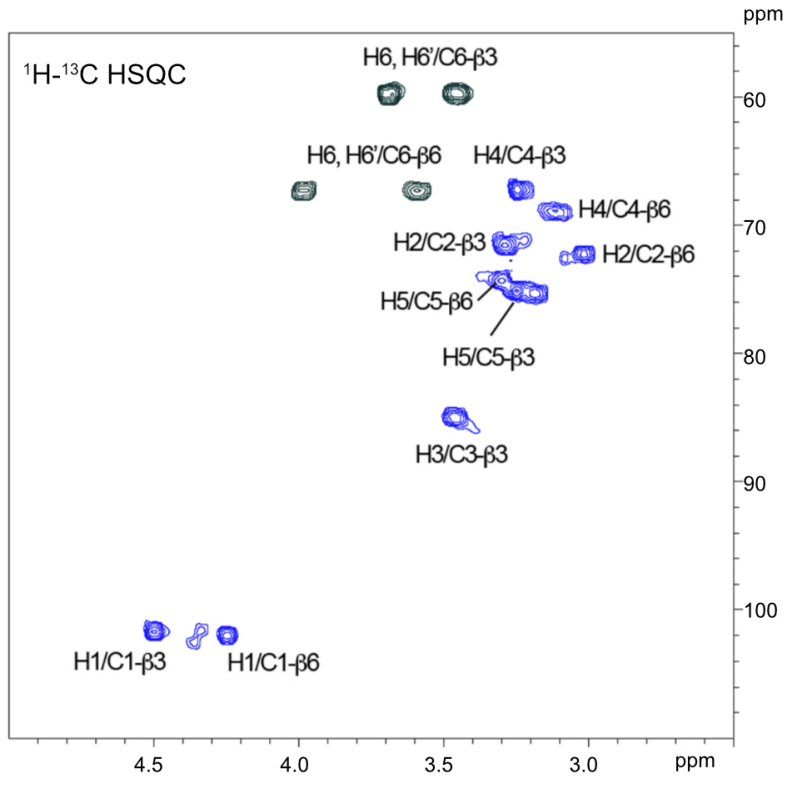

\begin{tabular}{lc}
\hline Residues & $\%$ \\
\hline t-Glc & 26.2 \\
3-Glc & 21.4 \\
4-Glc & 14.2 \\
6-Glc & 17.9 \\
2,3-Hex & 12.1 \\
3,6-Glc & 8.2 \\
\hline
\end{tabular}

Supplementary Figure 4. Structural analysis of phosphorylated $\beta 3$-glucan isolated from CNCM I-3856 yeast. (A) ${ }^{31} \mathrm{P}-\mathrm{NMR}$ spectrum and $(\mathrm{B}){ }^{1} \mathrm{H}-{ }^{31} \mathrm{P}-\mathrm{HSQC}$ NMR spectra, (C) GC-MS linkage chromatogram, and (D) ${ }^{1} \mathrm{H}-{ }^{13} \mathrm{C}-\mathrm{HSQC}$ NMR spectrum of phosphorylated $\beta 3$-glucan (acquisition at $400 \mathrm{MHz} N M R, d 6-\mathrm{DMSO}+\mathrm{D}_{2} \mathrm{O}$, 353K). X correspond to non-carbohydrate contaminants. 
A

\begin{tabular}{|c|c|}
\hline Glycan unit & of integrations (ppm) \\
\hline 4aglucan-linear+terminal-4aGlc & $5.45-5.30$ \\
\hline a-mannan-I & $5.3-5.25$ \\
\hline a-mannan-II & $5.18-5.14$ \\
\hline a-mannan-III & $5.13-5.09$ \\
\hline a-mannan-IV & $5.09-5.03$ \\
\hline 4,6aGlc-branching & $5.01-4.94$ \\
\hline a-mannan-V & $4.92-4.90$ \\
\hline $3 \beta$ glucan-linear & $4.81-4.76$ \\
\hline ter-glc $\beta 6$ & $4.76-4.71$ \\
\hline 3,6ßGlc-branching & $4.59-4.55$ \\
\hline $6 \beta g l u c a n-l i n e a r$ & $4.55-4.49$ \\
\hline
\end{tabular}

B

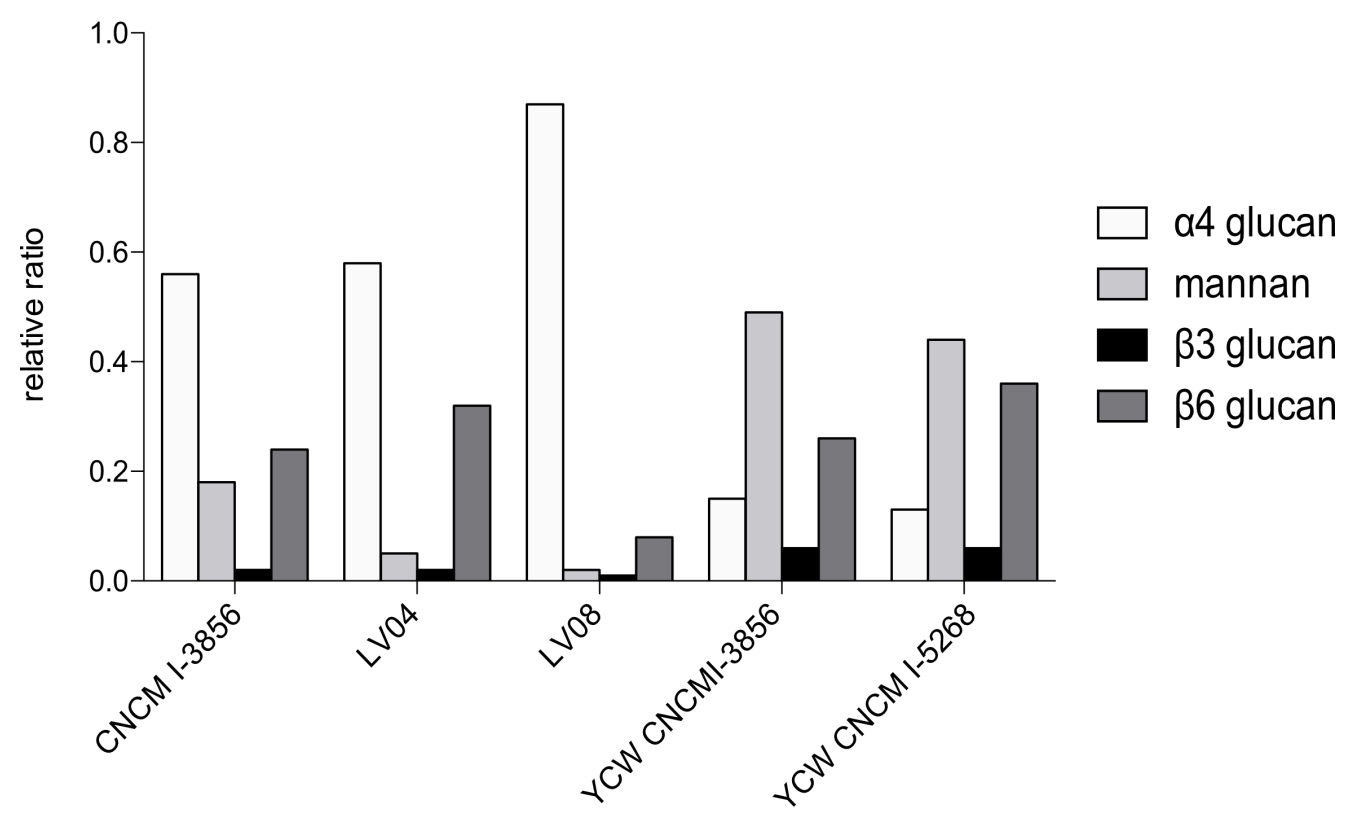

Supplementary Figure 5: Estimation of the proportions of individual polysaccharides in the soluble glucan fraction isolated from five samples. (A) Integration parameters on ${ }^{1} \mathrm{H}$ NMR spectra and (B) Calculated proportions of polysaccharides in each sample. 
A

\begin{tabular}{lcccc}
\hline & CNCMI-3856 & LV04 & LV08 & YCW CNCMI-5268 \\
\hline mannose & $9.82 \%$ & $11.9 \%$ & $1.4 \%$ & $36.1 \%$ \\
\hline glucose & $90.2 \%$ & $88.1 \%$ & $98.6 \%$ & $63.9 \%$ \\
\hline
\end{tabular}

B

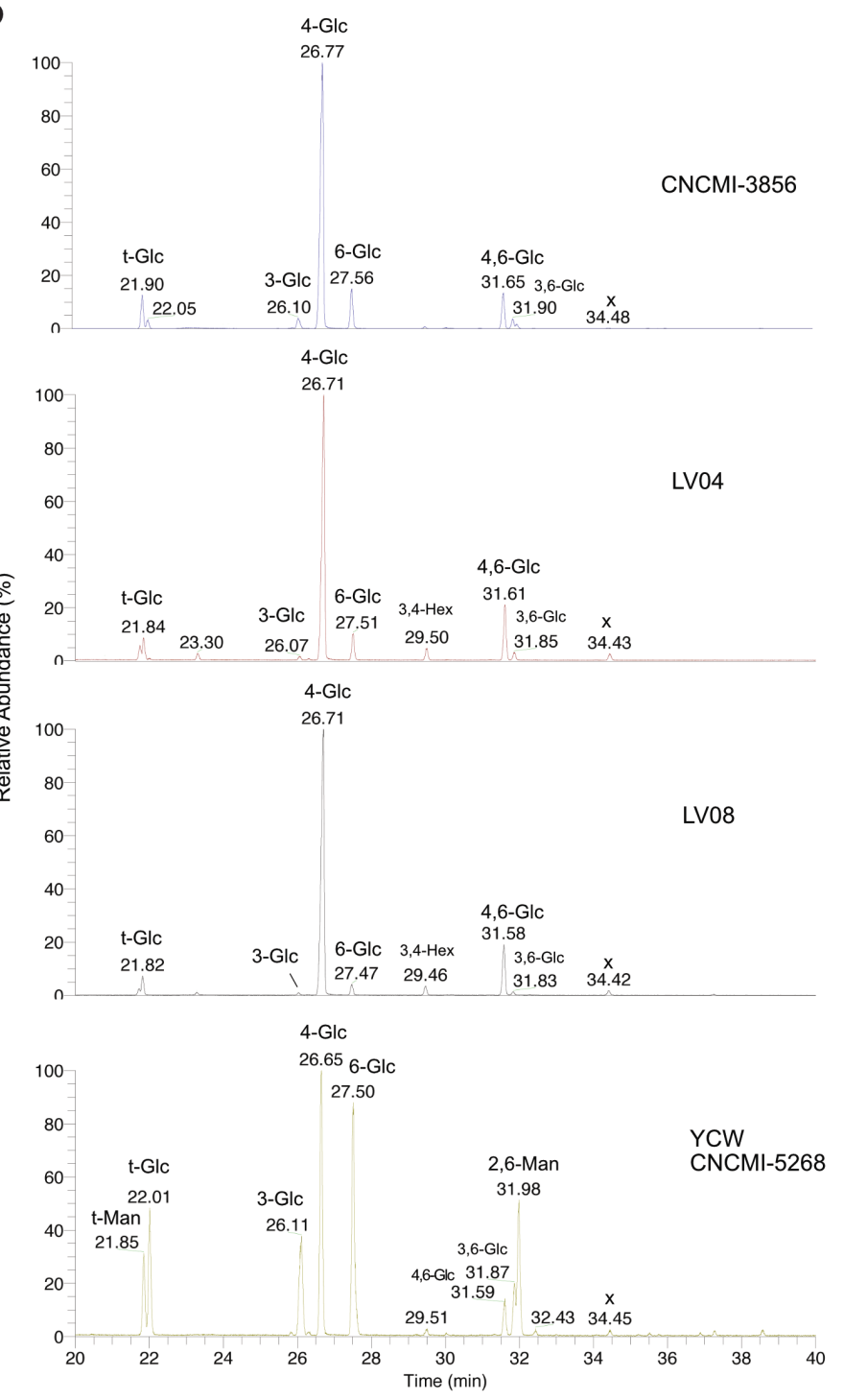

Supplementary Figure 6. Comparison of soluble glucan fractions isolated from four different yeast preparations. (A) Relative monosaccharide composition and (B) Linkage analyses of the soluble glucan fractions. 
Supplementary table 1 . Chemical shifts (ppm) of ${ }^{1} \mathrm{H}$ and ${ }^{13} \mathrm{C}$ of the glycosyl residues of mannan, dissolved in $\mathrm{D}_{2} \mathrm{O}$ and measured at $300 \mathrm{~K}$. These values were deduced from the interpretation of the $1 \mathrm{D}-{ }^{1} \mathrm{H} N M R$, $2 \mathrm{D}-{ }^{1} \mathrm{H}-{ }^{1} \mathrm{H}$ COSY, TOCSY, and ${ }^{1} \mathrm{H}-{ }^{13} \mathrm{C}$ HSQC spectra

\begin{tabular}{|c|c|c|c|c|c|c|c|c|}
\hline & & 1 & 2 & 3 & 4 & 5 & 6 & $6^{\prime}$ \\
\hline \multirow{2}{*}{$-2) \operatorname{Man}(\alpha 1,2)$} & $\mathrm{H}$ & 5.29 & 4.12 & 3.96 & 3.77 & 3.88 & - & - \\
\hline & C & 101.77 & 79.85 & 71.76 & 68.07 & 74.65 & - & - \\
\hline \multirow[t]{2}{*}{$\operatorname{Man}(\alpha 1,3)$} & $\mathrm{H}$ & 5.15 & 4.08 & 3.89 & 3.66 & 3.79 & - & - \\
\hline & C & 103.59 & 71.4 & 71.73 & 68.24 & - & - & - \\
\hline \multirow[t]{2}{*}{$-2,6) \operatorname{Man}(\alpha 1,6)$} & $\mathrm{H}$ & 5.11 & 4.03 & 3.94 & - & - & 4.03 & 3.68 \\
\hline & C & 99.31 & 80.23 & - & - & - & \multicolumn{2}{|c|}{67.02} \\
\hline $\operatorname{Man}(\alpha 1,2) \&$ & $\mathrm{H}$ & 5.06 & 4.23 & 3.97 & 3.77 & 3.83 & 3.92 & 3.77 \\
\hline -3)Man( $(\alpha 1,2)$ & C & 103.41 & 71.09 & 79.21 & 67.51 & 74.61 & \multicolumn{2}{|c|}{62.21} \\
\hline \multirow[t]{2}{*}{-6) Man( $\alpha 1,6)$} & $\mathrm{H}$ & 4.91 & 3.99 & - & - & - & - & - \\
\hline & C & 100.77 & 71.59 & - & - & - & - & - \\
\hline
\end{tabular}

“_" undetectable/undetermined value

Supplementary table 2. Chemical shifts (ppm) of ${ }^{1} \mathrm{H}$ and ${ }^{13} \mathrm{C}$ of the glycosyl residues of phosphorylated $\beta 3$ glucan, dissolved in d6-DMSO+ $\mathrm{D}_{2} \mathrm{O}$ and measured at $353 \mathrm{~K}$. These values were deduced from the interpretation of the $1 \mathrm{D}-{ }^{1} \mathrm{H}$ NMR, $2 \mathrm{D}-{ }^{1} \mathrm{H}-{ }^{1} \mathrm{H}$ COSY, TOCSY, and ${ }^{1} \mathrm{H}-{ }^{13} \mathrm{C} \mathrm{HSQC}$ spectra

\section{1}

2

3

$4 \quad 5$

6 $6^{\prime}$ 


\begin{tabular}{lcccccccc}
\hline-3$) \operatorname{Glc}(\beta 1,3)$ & $\mathrm{H}$ & 4.53 & 3.31 & 3.48 & 3.27 & 3.27 & 3.71 & 3.49 \\
& $\mathrm{C}$ & 102.9 & 72.6 & 86.1 & 68.4 & 76.2 & 60.82 & 60.82 \\
\hline $\mathrm{GIC}(\beta 1,3)$ & $\mathrm{H}$ & 4.39 & 3.12 & 3.26 & - & - & - & - \\
& $\mathrm{C}$ & 103.6 & 76.57 & - & - & - & - & - \\
\hline 3,6$) \mathrm{GIc}(\beta 1,3)$ & $\mathrm{H}$ & 4.36 & 3.27 & 3.41 & - & - & - & - \\
& $\mathrm{C}$ & 102.77 & - & 87.11 & - & - & - & - \\
\hline-6$) \mathrm{GIc}(\beta 1,6)$ & $\mathrm{H}$ & 4.28 & 3.04 & 3.21 & 3.14 & 3.33 & 4.02 & 3.62 \\
& $\mathrm{C}$ & 102.87 & 73.32 & 76.48 & 70.0 & 75.4 & 68.3 & 68.3 \\
& $\mathrm{C}$ & 100.77 & 71.59 & - & - & - & - & - \\
\hline
\end{tabular}

“_" undetectable/undetermined value

Supplementary table 3. Chemical shifts (ppm) of ${ }^{1} \mathrm{H}$ and ${ }^{13} \mathrm{C}$ of the glycosyl residues of soluble glucan (GGM) fraction, dissolved in $\mathrm{D}_{2} \mathrm{O}$ and measured at $431 \mathrm{~K}$. These values were deduced from the interpretation of the $1 \mathrm{D}-{ }^{1} \mathrm{H}$ NMR, $2 \mathrm{D}-{ }^{1} \mathrm{H}-{ }^{1} \mathrm{H}$ COSY, TOCSY, and ${ }^{1} \mathrm{H}-{ }^{13} \mathrm{C}$ HSQC spectra

\begin{tabular}{lcccccccc}
\hline & & 1 & 2 & 3 & 4 & 5 & $6 a$ & $6 \mathrm{~b}$ \\
\hline $\mathrm{Glc}(\alpha 1,4)+$ & $\mathrm{H}$ & 5.37 & 3.64 & 3.97 & 3.65 & 3.75 & 3.89 & 3.77 \\
$-4) \mathrm{Glc}(\alpha 1,4)$ & $\mathrm{C}$ & 101.5 & 72.82 & 74.81 & 79.13 & 74.91 & 62.59 & 62.59 \\
\hline-2$) \operatorname{Man}(\alpha 1,2)$ & $\mathrm{H}$ & 5.28 & 4.12 & 3.93 & 3.74 & - & - & - \\
& $\mathrm{C}$ & 102.1 & 79.4 & - & - & - & - & - \\
\hline $\operatorname{Man}(\alpha 1,3)$ & $\mathrm{H}$ & 5.16 & 4.09 & - & - & - & - & - \\
& $\mathrm{C}$ & 103.51 & - & - & - & - & & - \\
\hline$-2,6) \operatorname{Man}(\alpha 1,6)$ & $\mathrm{H}$ & 5.11 & 4.03 & - & - & - & - & - \\
& $\mathrm{C}$ & 99.94 & 79.7 & - & - & - & & - \\
\hline $\operatorname{Man}(\alpha 1,2) \&$ & $\mathrm{H}$ & 5.07 & 4.08 & - & - & - & 4.01 & 3.71 \\
$-3) \operatorname{Man}(\alpha 1,2)$ & $\mathrm{C}$ & 103.72 & 71.3 & - & - & - & 67.4 & 67.4 \\
\hline
\end{tabular}




\begin{tabular}{lcccccccc}
\hline$-4,6) \mathrm{GIC}(\alpha 1,6)$ & $\mathrm{H}$ & 4.98 & - & - & - & - & - & - \\
& $\mathrm{C}$ & - & - & - & - & - & - & - \\
\hline-6$) \operatorname{Man}(\alpha 1,6)$ & $\mathrm{H}$ & 4.91 & - & - & - & - & - & - \\
& $\mathrm{C}$ & 101.2 & - & - & - & - & - & - \\
\hline-3$) \mathrm{GIc}(\beta 1,3)$ & $\mathrm{H}$ & 4.78 & 3.58 & - & - & - & - & - \\
& $\mathrm{C}$ & 104.19 & - & - & - & - & - & - \\
\hline $\mathrm{GIC}(\beta 1,6)$ & $\mathrm{H}$ & 4.73 & 3.37 & - & - & - & - & - \\
& $\mathrm{C}$ & 104.3 & - & - & - & - & - & - \\
\hline $\mathrm{Glc}(\beta 1,3)$ & $\mathrm{H}$ & 4.65 & - & - & - & - & - & - \\
& $\mathrm{C}$ & - & - & - & - & - & - & - \\
\hline$-3,6) \mathrm{GIC}(\beta 1,6)$ & $\mathrm{H}$ & 4.56 & 3.54 & 3.78 & - & - & - & - \\
& $\mathrm{C}$ & 103.8 & 74.09 & 86.27 & - & - & - & - \\
\hline-6$) \mathrm{GIc}(\beta 1,6)$ & $\mathrm{H}$ & 4.53 & 3.35 & 3.52 & 3.46 & 3.64 & 4.22 & 3.88 \\
& $\mathrm{C}$ & 104.2 & 74.7 & 77.35 & 71.25 & 76.6 & 70.59 & 70.59 \\
\hline
\end{tabular}

“_" undetectable/undetermined value

Ciucanu, l., \& Kerek, F. (1984). A simple and rapid method for the permethylation of carbohydrates. Carbohydrate Research, 131(2), 209-217.

Hakomori, S. (1964). A Rapid Permethylation of Glycolipid, and Polysaccharide Catalyzed by Methylsulfinyl Carbanion in Dimethyl Sulfoxide. J Biochem, 55, 205-208. 